\title{
Çevresel Tehdit, Çevresel Bilinç Ve Çevresel Tutum, Çevre Odaklı Davranışı Etkiler Mi? Çanakkale Sivil Toplum Kuruluşları Örneği ${ }^{*}$
}

\author{
Bahattin HAMARAT** \\ Ozan GÜLER*** \\ Erol DURAN**** \\ Murat GÜMÜŞ***** \\ Ekrem TUFAN******
}

\section{Özet}

Bu araştırma iki bölümden oluşmaktadır. Araştırmanın I. bölümünde sivil toplum kuruluşlarında yer alan sivil yurttaşların çevresel tehdit algılamaları ve çevresel bilinçlerinin çevre merkezli davranışlarına etkisi yapısal eşitlik modeli (YEM) ile araştırılmıştır. Veri seti Çanakkale merkez ilçede sivil toplum kuruluşlarında yer alan 437 yurttaştan anket tekniğiyle elde edilmiştir. YEM sonucunda sivil yurttaşların çevresel tehdit algılamasının, çevresel bilinç düzeyini etkilediği ve aynı zamanda çevresel davranışı da etkilediği belirlenmiştir. Çevresel tehdit algılamasının çevresel bilinç değişiminin \%39'ini açıkladığ değişimin \%56'sını çevresel tehdit algılaması ile çevresel bilincin birlikte açıkladığı belirlenmiştir. Yapısal modelde kullanılan tüm değişkenler arasında pozitif ilişkiler belirlenmiş ve ölçekte yer alan her bir değişkenin çevre merkezli davranışı olumlu yönde etkilediği belirlenmiştir. Araştırmanın II. bölümünde sivil yurttaşların çevresel bilinçlerinin ve

*Bu çalışma“ÇOMÜ Bilimsel Araştırma Projeleri Komisyonu Başkanliğı tarafından 2011/092 Nolu proje ile desteklenmiştir".Ayrıca çalışmanın bir bölümü 2nd Advances in Hospitallity and Tourism Marketing E Conference 31 May-3 June 2012. Corfu, Greece'de bildiri olarak sunulmuştur.

**Öğr.Gör.Turizm Fakültesi, Çanakkale Onsekiz Mart Üniversitesi Çanakkale.

b_hamarat@hotmail.com

***Arş.Gör. Turizm Fakültesi, Mersin Üniversitesi. Mersin ozanguler17@hotmail.com

****Dr. Turizm Fakültesi, Çanakkale Onsekiz Mart Üniversitesi. Çanakkale. erolduran79@hotmail.com

*****Prof.Dr. Turizm Işletmeciliği ve Otelcilik Yüksek Okulu, Batman Üniversitesi Batman. muratgumus@yahoo.com

******Doç.Dr. Turizm Fakültesi, Çanakkale Onsekiz Mart Üniversitesi Çanakkale. etufan@yahoo.com 
Sosyal Bilimler Dergisi 27

çevresel tutumlarının çevre merkezli davranışlarına etkisi yapısal eşitlik modeli ile araştırılmıştır. Araştırmada veri seti olarak 436 kişiye ait anket tekniği ile elde edilen verilerden yararlanılmıştır. Sivil yurttaşların çevresel bilinçlerinin, çevresel tutumlarını etkilediği ve aynı zamanda çevresel davranışı da etkilediği belirlenmiştir. Çevresel bilincin çevresel tutum değişiminin \%63'ünü açıkladığı belirlenirken, Çevre odaklı davranıştaki değişimin \%72'sını çevresel bilinç ile çevresel tutumun birlikte açıkladığı belirlenmiştir. Araştırmanın I. bölümünde olduğu gibi tüm değişkenler arasında pozitif ilişkiler belirlenmiş ve değişkenlerin çevre merkezli davranışı olumlu etkilediği belirlenmiştir.

Anahtar kelimeler: Çevresel tehdit, Çevresel bilinç, Çevresel tutum, Çevre merkezli davranış, Yapısal eşitlik modeli, Sivil toplum Örgütleri.

\title{
Does Environmental Threat, Environmental Consciousnes, And Environmental Attitude Affect Environment Based Behaviour? The Case of Ngo's In Çanakkale
}

\begin{abstract}
This research Project consists of two parts. In Part I, the effect of environmental threat perceptions and environmental consciousness on environment-oriented behaviors of civic citizens that are the members of non-govermental organizations (NGO's) were analysed through structural equation modelling (SEM). The data set was obtained by a questionnaire form from 437 citizens who are the members of NGO's those performing in Çanakkale city center. SEM findings revealed that environmental threat perception of civic citizens have impact on both environmental consciousness level and environmental behavior. It was found that environmental threat perception explains 39 percent of environmental consciousness level, whereas environmental threat perception and environmental consciousness, together explain 56 percent of changes in environment-oriented behavior. Due to SEM analysis, all the variables included in SEM modelling have positive relations and each of the variables have impact on environment-oriented behavior. In Part II, the effect of environmental consciousness and environmental attitudes on environmentoriented behavior of civic citizens was analysed by the mentioned analysis. Data obtained from 436 participants were used. It was found that environmental consciousness of civic citizens influenced both environmental attitudes and environmental behavior. Environmental consciousness explains 63 percent of changes in environmental attitudes, and both
\end{abstract}


environmental consciousness and environmental attitudes, together, explain 72 percent of changes in environment-oriented behavior. Similar to the findings of Part I, all variables have positive relations and all the variables have positive impact on environment-oriented behavior.

Key Words: Environmental threat, environmental consciousness, environmental attitude, environment-oriented behavior, structural equation modelling, Non-govermental organizations.

\section{Giriș}

Son yıllarda çevresel sorunların verdiği zararların ortaya çıkması toplumlarda çevresel kaygıyı arttırmış ve çevre merkezli davranışların gelişmesine neden olmuştur. Benzer şekilde bilim insanları ve çevre örgütleri çevre kirliliği ve onun olumsuz bir sonucu olan küresel 1sınmayla ilgili kaygılarını daha yüksek sesle dile getirmektedir. Çeşitli ulusal ve uluslararası sivil toplum örgütlerinin, politikacılar ve yöneticiler üzerinde güçlü baskılar oluşturması ve tüketici bilincinin gelişmesindeki artışlar nedeniyle işletmeler ve çeşitli örgütler çevre kirliliğini önlemek, zararlı atıkları azaltmak hatta tamamıla ortadan kaldırmak amacıyla çevre merkezli davranışlar geliştirmeye yönelmişlerdir.

Çevreye karşı duyarsız olan toplumlarda bireylerin, çevresel tutum ve davranış geliştiremeyecek olması nedeniyle çevreye sorun yaratmaya devam edeceği şüphesizdir. Dolayısıyla sürdürülebilir bir çevre için bireylerin çevre hakkındaki görüş ve davranışlarının belirlenmesi gerekir. Sosyolojik olarak bireylerin çevre merkezli ya da çevre merkezsiz davranış geliştirmeleri bireylerin çevre sorunlarını ne derece tehdit olarak algıladıklarının da bilinmesi gerekmektedir. Bireyin bir çevre sorununu kendince ne derece tehdit oluşturduğunu ya da oluşturmadığını entelektüel olarak belirleyebilmesi için, o tehdit hakkında yeterli düzeyde bilgiye sahip olması gerekmektedir. Dolayısıyla bireylerin çevresel tehdit algısı ve çevre sorunları ya da eko sistem hakkındaki bilgileri, bilinçli davranışa dönüşebilecektir.

Toplumların çevre sorunlarına olan duyarlılığı 1960'lı yılların sonlarına rastlamaktadır. II. Dünya Savaşının ardından yaklaşık 30 yıl süre ile uygulanan Fordist üretim biçimi, 1973 yıllarından itibaren günümüzü de içine alacak şekilde derin bir ekonomik krize girmiş, bu sürece tüm dünya ülkeleri dahil olmuştur. Tüketime dayalı büyüme modellerinden vazgeçilmesiyle "sürdürülebilir kalkınma" olarak genel bir kavramla adlandırılan yeni bir döneme girilmiştir. Sürdürülebilir kalkınma kavramı, 1980'lerde Birleşmiş Milletlerin yoksulluk, aşırı nüfus artışı, açlık, kuraklık, 
Sosyal Bilimler Dergisi 29

orman tahribatı ve iklim değişikliği gibi büyük sorunları incelemeye başlamasıyla ortaya atılmıştır. Birleşmiş Milletler (BM), 1987 Brundtland Raporunda sürdürülebilir kalkınmayı; gelecek kuşakların kendi ihtiyaçlarını karşılayabilmelerini tehlikeye sokmaksızın bugünün kuşaklarının ihtiyaçlarını karşılayabilecek kalkınma olarak tanımlamıştır (WTO, 1998). Brezilya'nın Rio de Janerio kentinde düzenlenen 1992 Dünya Zirvesi'nde, özellikle yoksul kesimin hayat kalitesini iyileştirmeye ve sürdürmeye yönelik "Gündem 21" eylem planının onaylanması, sürdürülebilir gelişme için önemli bir itici güç olmuştur (Keating, 1996: 137). Rio zirvesinin sonuç belgeleri daha sonra düzenlenen $\mathrm{BM}$ toplantılarının gündemini de etkilemiştir. Dünya Nüfus ve Kalkınma Konferansı (Kahire, 1994), Dünya Sosyal Kalkınma Zirvesi (Kopenhag, 1995) İkinci İnsan Yerleşimleri Konferansı - Habitat II (İstanbul, 1996) ve Binyıl Zirvesi (New York, 2000) bunlardan bazılarıdır (Demir ve Çevirgen, 2006: 96).

Sürdürülebilirlik ve Sürdürülebilir kalkınma kavramları yaşamın her noktasına yerleşmiş, tarımda, sanayide, turizmde vb. pek çok sektörde sürdürülebilirlik kavramı ön plana çıkmıştır. Bu bağlamda, kalkınma ya da bölgesel gelişmede önemli bir alt sektör olarak nitelediğimiz turizm, çevre ve doğal kaynaklarla olan sıkı ilişkisi nedeniyle kalkınma ve çevre ilişkisinin uyumluluğa dönüştürülmesi gereğini ortaya koymaktadır (Duran, 2011). İşte bu noktada, çevre ve ekonomi ile turizmi gittikçe artan bir önemle birbirinin parçası olarak geliştirmek, çevre kalitesini sürdürmek, kalkınmayı eşitlemek temel hedeflerini içeren sürdürülebilir turizm kavramı ortaya çıkmaktadır (Beyhan ve Ünügür, 2005: 80). Dünyada en hızlı büyüyen sektörler içinde yer alan turizm, doğal ve kültürel kaynaklara bağımlıdır. Dolayısıyla, bu kaynakların zarar gördüğü bir ortamda turizmden söz etmek mümkün değildir. Bu bakımdan sürdürülebilirlik kavramı turizm açısından büyük önem taşımaktadır. Turizmde sürdürülebilir bir gelişmenin sağlanabilmesi için ev sahibi bölgenin doğal, tarihi, kültürel kaynaklarının, temel ekolojik süreçlerinin ve biyolojik çeşitliliğinin zarar görmemesi ve devamının sağlanması gerekmektedir (Demir ve Çevirgen, 2006: 99).

Yeni dönemde ekonomik ve sosyal dayanaklar da değişmiştir. Bu süreçte; bilim ve teknolojideki gelişim, dünya nüfusunun artışı ve toplumların sanayileşmenin yarattığı kirlilik konusunda bilinçlenmeleri sonucunda, çevreyle ilgili sorunlar ekonomik sorunlarla birlikte ele alınmaya başlanmıştır. Bu olguya, doğayı ve doğal kaynakları gelecek kuşakları da planlayarak akılcı bir biçimde kullanma isteği de dahil olmuştur. Artık dünyamızda su kirliliğii, toprak kirliliğ̈i, besin kirliliği (kalıntılar) gibi çeşitli şekillerde kendini gösteren olumsuzlukların yerine temiz su kaynakları, organik besin, yenilenebilir enerji ya da çevre dostu 
enerji kaynakları gibi çevre dostu ürünlerden söz edilir duruma gelinmiştir. $\mathrm{Bu}$ düşünceler doğrultusunda da politikalar üretilmekte ya da üretilmesi için yönetimler üzerinde baskı gücü oluşturulmaktadır. Bu baskı unsurlarından birisi de Sivil Toplum Kuruluşları STK'lardır. Bu bağlamda STK üyelerinin çevre ile ilgili düşüncelerinin ve öngörülerinin belirlenmesi önemli olmaktadır.

\section{Literatür}

1962 yılında Amerika'da tarım ilaçlarının çevreye verdiği öldürücü etkilerini kaleme alan Ekolog Rachel Carson'un yazmış olduğu Silent Spring adlı kitapta tarım alanında kullanılan ot ve böcek öldürücü (pestisit) kimyasalların çevreye zararından bahsedilmiştir. Rachel Carson'un kitabı ile birlikte çevre tanımı kamu politikalarına girmeye başlamış ve 2004 yılında Wangari Muta Maathai, "sürdürülebilir kalkınma, demokrasi ve barışa yaptığı katkılarından dolayı Nobel barış ödülünü elde etmiştir. Wangari Muta Maathai 1977 Yeşil Kuşak Hareketini (Green Belt Movement) başlatmış ve mücadelesi daha çok demokrasi, insan hakları ve çevre koruma alanlarında gerçekleşmiştir.

Betsill ve Corell (2001), "Sivil Toplum Kuruluşlarının Uluslararası Çevresel Müzakerelerdeki Etkisi" isimli çalışmalarında, Sivil Toplum Kuruluşlarının, uluslararası çevresel müzakerelerdeki etkilerini değerlendirmek için analitik bir çerçeve hazırlamışlardır. Böylelikle Sivil Toplum Kuruşlarının küresel çevre politikalarındaki rolünün teorik olarak geliştirilmesi hedeflenmiştir. Literatürdeki eksikliğin farkına varan yazarlar, çeşitli yollarla bu konunun üzerine giderek, literatür katkısı yapmayı planlamışlardır. Çalışmada tartışılan konulardan bir diğeri de, Sivil Toplum Kuruluşlarının çevre müzakerelerinde, elindeki bilgileri paylaşma niyetinin yani müzakere sürecini ve çıtılarını etkileyen bu sürecin olmaması durumunda nelerin olabileceğidir. Müzakerelerde, STK'ların etkisini daha sistematik açıdan değerlendirmek için önemli bilgi ve analizlerin ortaya çıkartabileceği belirtilmiştir

Aguilar (2002), “Arjantin 'deki Sivil Toplum Kuruluşları" isimli çalışmasında, Arjantin çevresel hareketi ile ilgili birçok kişi ile bir seri görüşmeler yapmıştır. Konu ile ilgili yazılı literatüre kaynağının eksik olması, yazarı ilk elden, konu ile ilgili gerçek katılımcılardan Arjantin 'in son 30 yılında gerçekleşen çevre ile ilgili sorunları dinlemiştir. Bu sebeple çoğu analitik sonuç, yazarın derinlemesine mülakat yöntemine dayanmaktadır. Çalışma birinci bölüm askeri yönetimden, demokratik hükümetlere geçiş sürecindeki Sivil Toplum Kuruluşlarının Arjantin`deki tarihsel gelişimine değinmiştir. İkinci bölüm ise Sivil Toplum Kuruluşlarının karar vericilerin 
Sosyal Bilimler Dergisi 31

fikirlerini etkilemeye çalıştığı süreçte yaşadığı geleneksel, yasal ve kültürel olayları ve fırsatları değerlendirmektedir. Özellikle, Sivil Toplum Kuruluşlarının yasaları geliştirme, güçlendirme ve çevresel etki yaratma süreci mercek altına alınmıştır.

Nomuro, Hendarti ve Abe. (2003), “Gelişmekte olan Ülkelerde Sivil Toplum Kuruluşları Eğitim Merkezleri: Rolü, Önemi ve Değişim Perspektifinden Başarıya Giden Adımlar" isimli çalışmasında, Endonezya`da bir STK eğitim merkezi olan PPLH- Seloliman`a yoğunlaşmıştır. Yazarın bu merkeze yoğunlaşmasının sebeplerinden birincisi, bu merkezin çevresel eğitim odaklı olması ve çevre eğitimin yaygınlaşmasına katkı yapması ikincisi ise bu merkezin diğer birçok STK'lardan farklı olarak finansal olarak bağımsız bir STK olmasıdır. Çalışmada bu PPLH-Seloliman kuruluşu, E.M. Rogers'ın ortaya koyduğu "Değişim Unsuru" (1983-1995) yani kaynakların yine diğer kaynaklar arasındaki örneğin danışma, bilgi, materyaller, çevre, fonlar ve diğerleri arasında akışını sağlamak ve tüketici sistemi (programın ve projenin hedef kitlesi) teorisine göre değerlendirilmektedir. Bu konular açısından PPLHSoleliman Sivil toplum kuruluşu analiz edilmekte ve "Değişim Unsuru" teorisinin bir Çevresel STK açısından öneminin altı çizilmeye çalışılmaktadır.

Al-Rabaani and Al-Mekhlafi (2009), "Sultan Qaboos Üniversitesi Öğrencilerinin Bazı Çevresel Sorunlara Karşı Gösterdikleri Davranışlar ve Bu Problemleri Azaltmada Niyetleri" isimli çalışmalarında, 5 farklı fakülteden toplam 317 öğrenciye 48 sorudan oluşan ve 5 farklı bölüme ayrılan bir anket uygulaması yapmışlardır. Çalışma sonuçları kadınların, erkeklerden daha pozitif çevresel davranışlar gösterdiğini, çevresel problemler olan su, hava kirliliği, atıklar gibi konularda öğrenciler arasında davranış farklılığı gözlenmediği, yalnızca Eğitim fakültesi ile Ziraat fakültesi öğrencileri arasında enerji konusunda davranış farklılıkları görüldüğü belirlenmiştir. Buna göre Eğitim Fakültesi öğrencileri daha pozitif davranışlar göstermektedir. Ayrıca Çevresel kirliliği azaltma davranışlarında, farklı cinsiyet ve fakülteler arasında istatistiksel anlamda önemli farklılıklar bulunmamıştır.

Zecha S. (2010), "Güney İspanya (Asturian) ve Güney Almanya (Bavarian) Gençlerinin Çevresel Bilgi, Davranış ve Hareketleri" isimli çalışmasında, 2007 yılında, yaşları 14 ila 15 arasında değişen 900 Bavarian ve 182 Asturian okul çağı çocuklarının üzerinde yapılan anket çalışmasından toplanan verilerden ortaya çıkan sonuç yayımlanmıştır. Sonuçlar, kültürel farklılıkların; çevresel bilgi, davranış ve hareketler açısından farklılıklar yarattığını göstermiştir. Ayrıca çeşitli bağımsız değişkenlerin 
değerlendirilmesi ile Bavarian ve Austrainlar gençleri arasında, kişisel davranış ve hareketlerine göre, çevresel bilgi ve davranışları arasında önemli istatistiksel farklılıklar olduğu belirlenmiştir.

Hebel, Montpied and Fontanieu (2010), “Öğrencilerin Çevreye Karşı Davranışları: Fransız Ortaokul Öğrencileri Üzerine Bir Çalışma" isimli çalışmasında, Fransa` da 2008 yılında yürütülen Fen Bilimleri Eğitim Projesi kapsamında oluşturulan anket sorularının ortaokul öğrencilerine uygulanması ile 2124 Fransız öğrenciden veri toplanmıştır. Çevresel davranışlar egosantrizm, antroposantrizm ve egosantrizm gibi üç farklı açıdan değerlendirmişlerdir. Bu üç konu için cinsiyet bakımından farklılıklar olduğunu gösterdiğini belirlemişlerdir. Elde edilen bulgular çerçevesinde yazarlar, bu üç çevresel davranış tarzı ile çevresel konuları öğrenmeye yönelik eğilimler arasında ilişkiler olduğunu göstermişlerdir.

Yavetz, Goldman and Peer (2007), “Öğretmenlik Stajlarında Çevresel Eğitim; Yeni Başlayan Öğrencilerin Çevresel Davranış, Bilgi ve Tutumları" isimli çalışmalarında, İsrail'de bulunan üç farklı öğretmenlik bölümü birinci sınıf öğrencilerinden 765 'i ile görüşmüşlerdir. Araştırmacılar, öğrencilerin alışkanlıkları ile çevresel davranışları arasında olası ilişkileri araştırmışlardır. Ayrıca araştırmada öğrenciler arasında, çevre bilinci ve çevresel davranışlarının farklılık gösterip göstermediği de araştırılmıştır. Araştırma sonucunda, öğrencilerin her ne kadar çevresel bilgileri sınırlı olsa da çevresel tutumlarının pozitif olduğu bulunmuştur. Çevre bölümlerine yakın alanlarda okuyan öğrencilerin, çevresel bilgi ve davranışları, diğer bölümlerdeki öğrenciler ile kıyaslandığında daha yüksek olduğu bulunmuştur.

Vlaardingerbroek ve Taylor (2007), “Lübnan`daki Öğretmen Adaylarının Çevresel Bilgi ve Davranışlarındaki Tutumları: Karşılaştırmalı Bir Çalışma" isimli çalışmada, Avustralyalı ve Lübnanlı birinci ve ikinci sınıf öğrencilerinin, çevresel bilgi ve davranışları arasında karşılaştırma yapılmıştır. Toplam 87 geri dönüşün sağlandığı çalışmada, Avustralyalı öğrenciler, küresel çevresel sorunlar ile ilgili bilgileri ışığında, ülkelerinin ulusal çevre sorunlarına yaklaşık yanıtlar verirken, Lübnanlı öğrencilerin bunun uzağında kaldıkları gözlenmiştir. Öğrenciler çevresel davranış ölçeklerinde pozitif skorlar gösterseler de, okulda çevresel eğitimin, çevresel sorunları hesaplamada ne kadar etkili olacağı konusunda daha çok şüpheci yaklaştıkları gözlenmiştir.

Yılmaz, Yıldız ve Arslan (2011), üniversite öğrencilerinin çevresel duyarlılıkları ve tutumlarının çevresel davranışlarına etkisi bir model yardımıyla araştırılmıştır. Geliştirilen modelde çevresel duyarlılığın çevresel 
Sosyal Bilimler Dergisi 33

tutumdaki değişimin $\% 54^{\prime}$ ünü, çevresel tutumların ise çevresel davranıştaki değişimin \%28' ini açıkladığı belirlemişlerdir.

\section{Yöntem}

\subsection{Amaç ve Önem}

Çalışmanın amacı, Çanakkale merkezde yer alan Sivil Toplum Kuruluşlarında etkinlik gösteren sivil yurttaşların çevresel tehdit algılamaları, çevresel bilinçleri ve çevresel tutumlarının çevre odaklı davranışlarını nasıl etkilediğini ortaya koymaktır. Bu bağlamda sivil yurttaşların çevresel tehdit algılamaları, çevresel bilinçleri ve çevresel tutumları belirlenecektir. Bireylerin bu özellikleri ile çevre odaklı davranışları arasında olası ilişkiler iki ayrı aşamada belirlenecektir. Birinci aşamada sivil yurttaşların çevresel tehdit ve çevresel bilinçlerinin çevre merkezli davranışlarına olan ilişkileri incelenecektir. Araştırmanın ikinci aşamasında çevresel bilinç ve çevresel tutumlarının çevre merkezli davranışlarına olan ilişkileri incelenecektir.

Çeşitli ülkelerde olduğu gibi ülkemizde de sivil toplum kuruluşlarının merkezi yönetimlerde ve yerel yönetimlerde ağırlıkları her yıl artmakta ve alınan kararlarda belirleyici rol oynamaktadırlar. Sürdürülebilir bir çevre için sivil toplum kuruluşlarında görev alan yurttaşların çevre hakkındaki bilgi, tutum ve davranışlarının belirlenmesi gelecekte yönetimlerin nasıl kararlar alabileceğinin de öngörüsünü oluşturacaktır. $\mathrm{Bu}$ anlamda araştırma, katılımcı demokrasi bağlamında alınacak yerel çevre kararlarına destek vermesi açısından da önem arz etmektedir.

\subsection{Anakütle ve Örneklem}

Araştırmanın anakütlesini Çanakkale merkez ilçede 120 STK' da etkinlik gösteren sivil yurttaşlar oluşturmaktadır. STK'na ait çerçevenin oluştuğu bir liste Çanakkale Kent Konseyinden elde edilmiştir. Listede yer alan 120 STK bir tabaka olarak kabul edilmiş ve bu tabakalardan rast gele 30 STK seçilmiş ve bu STK'lara Kent konseyi sekretaryası tarafından 15'er anket gönderilmiştir. Ancak kimi STK'nın adresindeki hatalar ya da beklenen anketlerin dönmemesi üzerine kolayda örnekleme ile tüm STK'na ulaşılmaya çalışılmıştır. Ayrıca etkinliğine devam eden ve üyeleri bulunan STK'lara gidilerek yüz yüze anket formlarının doldurulması sağlanmıştır. Ayrıca STK'ların yapmış oldukları çeşitli etkinliklere katılarak örneklem yeter sayısına ulaşılmaya çalışılmıştır. Araştırmanın birinci aşaması için 437, 
ikinci aşaması için ise 436 sivil yurttaşa ait veriler araştırmanın örneklemini oluşturmuştur.

Örneklem hacminin belirlenmesinde "Kabul edilebilir hata düzeyini esas alan yöntem" kullanılmıştır. Ana kütledeki çevresel tehdit, bilinç, tutum ve davranışlara ilişkin oranlar bilinmediği için $p$ ve q değerleri 0,5 alınmış ve mümkün en büyük örneklem hacmine ulaşılmıştır. Anketin uygulanacağ 1 birim sayısı, $\mathrm{n}=\left\{\mathrm{z}^{2} \mathrm{pq}\right\} / \mathrm{d}^{2}$ formülü yardımıyla hesaplanan denklemde; 0,05 anlamlılık düzeyinde $z=1,96$; $d$ (duyarlılık) $=0,05$ ve $p$ ve $q$ değerleri 0,5 olmak üzere örneklem hacmi 384 olarak hesaplanmıştır.

\section{3. Ölçme Aracı}

Araştırmada kullanılan ölçek dört bölümden oluşmaktadır. Ölçeğin birinci bölümü sivil yurttaşların çeşitli özelliklerini belirlemeye yönelik 11 sorudan oluşmaktadır. Ölçeğin ikinci bölümü çevresel tehdit unsurlarını belirlemeye yönelik 14 sorudan oluşmaktadır. Ölçeğin skalası 6'lı olacak şekilde hazırlanmıştır. Çevresel tehdit algılamasında ölçeğin skalası 1 kesinlikle katılmıyorum, 5 kesinlikle katılıyorum olacak şekilde hazırlanmıştır. Eğer katılımının maddede geçen çevresel tehdit konusunda bilgisi yoksa veri analizinde 0 olarak kotlanmıştır. Ölçme aracının bir diğer bölümü ise katılımcıların Çevresel bilinç (Bilgi) düzeyini belirlemeye yönelik 13 sorudan oluşmaktadır. Çevresel bilinç soruları araştırmanın ikinci aşamasında 19 sorudan oluşmuştur. Çevresel bilinç sorularında 1 hiç katılmıyorum 5 ise tamamen katılıyorum olacak şekilde hazırlanmıştır. Ölçeğin son bölümü sivil yurttaşların çevre odaklı davranışını belirlemeye yönelik 12 sorudan oluşmaktadır. Araştırmanın ikinci bölümünde çevresel bilinç ölçeği çıkartılmış yerine çevresel tutum ölçeği yer almıştır. Sivil yurttaşların çevresel tutumunu ölçen ifadeler ise 21 sorudan oluşmaktadır. Tutum soruları da 1 hiç katılmıyorum 5 ise tamamen katılıyorum olacak şekilde hazırlanmıştır. Araştırmanın ikinci aşamasında çevresel davranış ölçeğinde 13 çevresel davranış sorusu yer almıştır. Soruların skalaları Çevresel bilinç ve tutum ölçeğindeki gibi derecelendirilmiştir. Ölçekte yer alan sorular literatür taramasından sonra çeşitli araştırmalarda kullanılan ölçeklerde kullanılan ifadelerden oluşturulmuştur.

Araştırmanın ilk aşamasında kullanılan veri matrisinde 17 sivil yurttaş çevresel tutum ölçeğine yanıt vermemiştir. Araştırmanın ikinci bölümünde sivil yurttaşların çevresel tutumları da modele dahil edileceğinden tutum ölçeğine eksik bilgi verenler ölçekten çıkarılmış yerine ankete katılan 16 kişi ilave edilmiş ve araştırmaya devam edilmiş̧ir. Tutum ölçeği iki ayrı bölümden oluşmaktadır. Bunlar Duygusal tutum ölçeği ve 
Sosyal Bilimler Dergisi 35

Bilinçsel tutum ölçekleridir. Ölçekte yer alan ifadeye ilişkin sevme, nefret etme, hoşlanma, korkma gibi duygulardan oluşan ifadelerden oluşan ölçek duygusal tutum ölçeği olarak değerlendirilmiştir. İfadede yer alan nesne, olay, insan, örgüt örgütsel davranış gibi görüşlerden oluşan genel bilgilere ve gerçeklere dayanan tutumlar Bilişsel tutum ölçeği olarak değerlendirilmiştir.

\subsection{Araştırma Modeli ve İstatistiksel Yöntem.}

Araştırmacılar veri setini oluştururken direk gözlenen veya ölçülen değişkenlerin yanında gözlenemeyen değişkenlerle de ilgilenirler. Bu değişkenler direkt gözlenemediğinden doğrudan ölçülemezler. Bu değişkenlere gizil (latent) değişkenler veya faktörler denilir. Yapısal eşitlik modelleri (YEM) gözlenen ve gözlenemeyen değişkenler arasındaki nedensel ilişkilerin sınanmasında kullanılan kapsamlı bir istatistiksel tekniktir. YEM gizil değişkenler seti arasında bir nedensellik yapısının var olduğunu ve gizil değişkenlerin gözlenen değişkenler aracilığıyla ölçülebildiğini varsayar (Yılmaz, 2004). YEM verilen bir modeldeki gözlenen değişkenlere ilişkin ölçüm hatalarını açıkça hesaba katan bir yöntemdir.

Araştırmanın ilk aşamasında, sivil toplum kuruluşlarında etkinlik gösteren yurttaşların, Çevresel Tehdit algılamaları, Çevresel Bilinçleri ve Çevre Odaklı Davranışları gizil değişken olarak belirlenmiştir. Ayrıca Çevresel tehdit ve çevresel bilinç değişkenleri ikinci düzey ölçüm modeline sahiptir. Üç gizil değişken arasındaki ilişkileri belirlemeye yönelik model Şekil 1'deki gibi belirlenmiştir. Modelde Yurttaşların Çevresel Bilinçlerine yönelik gizil değişkeni aynı zamanda aracı bir değişkendir. Sivil yurttaşların (SY) gizil değişkenlere yönelik kurulan hipotezler ise aşağıdaki gibidir.

$\mathrm{H}_{1}$ : SY'ların çevresel tehdit algılamaları arttıkça çevresel bilinçleri de artar.

$\mathrm{H}_{2}$ : SY'ların çevresel bilinçleri arttıkça çevre odaklı davranışları artar.

$\mathrm{H}_{3}$ : SY'ların çevre odaklı davranışlarının artışında çevresel bilinçleri aracı rol üstlenir.

$\mathrm{H}_{4}$ : SY'ların atıklara yönelik tehdit algısı çevresel tehdit algılamasını artırır.

H5: SY'ların nükleer ve kimyasal tehdit algılamaları çevresel tehdit algilamasını artırır.

H6: SY'ların iklim değişikliği-küresel 1sınma, ormansızlaşma gibi tehdit algılamaları çevresel tehdit algılamasını artırır.

$\mathrm{H}_{7}$ : SY'ların nükleer ve gen bilgisi çevresel bilincini artırır.

H8: SY'ların Yağmur ormanlarına ve sera gazlarına yönelik bilgisi, çevresel bilincini artırır.

H9: SY'ların enerji elde etme yöntemleri ve kullanımına yönelik bilgileri çevresel bilinci artırır. 


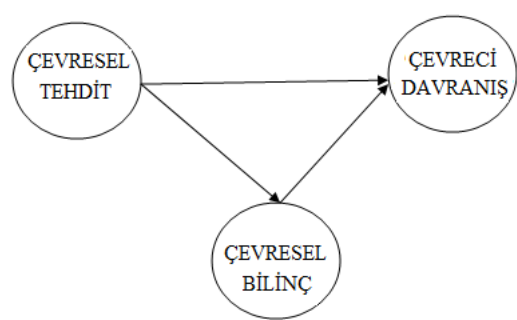

Şekil 1. Çevresel Tehdit Çevresel Bilinç ve Çevreci Davranış

Gizil Değişkenleri Arasındaki Yapısal Model

Araştırmanın ilk aşamasında sivil yurttaşların çevresel tehdit algılamaları ve çevreselsel bilinçleri, çevre odaklı davranışlarını nasıl etkilediğini görmeye çalışılmıştır. İkinci aşamasında ise çevresel bilinç ve çevresel tutumların çevreci davranışlara olan ilişkilerini görmeye çalışılacaktır.

Araştırmanın analizinde Yapısal modelin elde edilmesi için Lisrel hazır yazılımından yararlanılmıştır. Araştırmada 17 sivil yurttaş çevresel tutum ölçeğine yanıt vermediğinden veri matrisinden çıartılmıştır. Dolayısıyla Birinci bölümde ele alınan değişkenler yeniden düzenlenmiş ve bölüm ikide ele alınan değişkenlerle yeni boyutlar tanımlanmış ve güvenilirlik analizleri ve doğrulayıcı faktör analizleri tekrar hesaplanmıştır.

Araştırmanın ikinci bölümünde sivil toplum kuruluşlarında etkinlik gösteren sivil yurttaşların, Çevresel Bilinçleri, Çevresel tutum algılamaları ve Çevre Odaklı Davranışları gizil değişken olarak belirlenmiştir. Ayrıca çevresel bilinç ve çevresel tutum değişkenleri ikinci düzey ölçüm modeline sahiptir. Üç gizil değişken arasındaki ilişkileri belirlemeye yönelik model, Şekil 2'deki gibi belirlenmiştir. Modelde Yurttaşların Çevresel tutumlarına yönelik gizil değişkeni aynı zamanda aracı bir değişkendir. Sivil yurttaşların gizil değişkenlere yönelik kurulan hipotezler ise aşağıdaki gibidir.

$\mathrm{H}_{1}$ : Sivil yurttaşların çevresel bilinçleri arttıkça çevresel tutumları da artar.

$\mathrm{H}_{2}$ : Sivil yurttaşların çevresel bilinçleri arttıkça çevreci davranışları da artar.

$\mathrm{H}_{3}$ : Sivil yurttaşların çevresel tutumları arttıkça çevreci davranışları da artar.

$\mathrm{H}_{4}$ : Sivil yurttaşların çevre odaklı davranışlarının artışında çevreci tutumları aracı rol üstlenir.

$\mathrm{H}_{5}$ : Sivil yurttaşların yağmur ormanları ve gen bilgisi çevresel bilinci artırır.

$\mathrm{H}_{6}$ Sivil yurttaşların atıklara yönelik iklim değişikliği-küresel ısınma bilgisi çevresel bilinci artırır.

$\mathrm{H}_{7}$ : Sivil yurttaşların enerji elde etme bilgisi çevresel bilinci artırır.

$\mathrm{H}_{8}$ : Sivil yurttaşların olumlu çevresel bilişsel tutumları çevreci tutumlarını artırır. 
$\mathrm{H}_{9}$ : Sivil yurttaşların olumlu çevresel duygusal tutumları çevreci tutumlarını artırır.

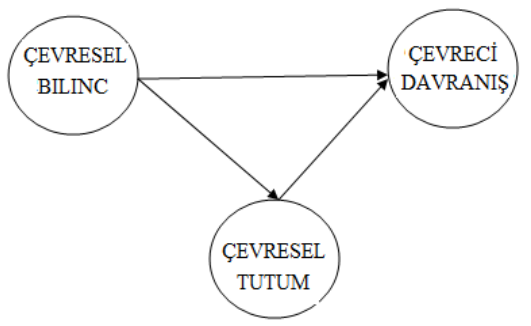

Şekil 2. Çevresel Bilinç, Çevresel Tutum ve Çevreci Davranış

Gizil Değişkenleri Arasındaki Yapısal Model

\section{Bulgular}

Araştırmanın ilk aşamasına yönelik bulgular aşağıdaki gibi elde edilmiştir. Araştırmaya katılanların \%62,7 erkek yurttaşlardan oluşmaktadır. Katılımcıların ortalama yaşı 38,20 standart sapması ise 13,39 olarak hesaplanmıştır. Medeni durumları ise \%61,6 sının evli, \%34,8'i ise herhangi bir çevre derneğine üye olduğu belirlenmiştir. Katılımcıların eğitimleri incelendiğinde \%41,4'ü Lisans, \%11,4'ü Lisansüstü eğitime sahip olduğu belirlenmiştir. Ön lisans eğitime sahip yurttaşların oranı ise \%21,3 olarak hesaplanmıştır. Ortalama aylık gelirleri ise 1599,03 ve standart sapması ise 1153,3 şeklinde hesaplanmıştır. Çevre ile ilgili son iki yıl içinde eğitim ya da seminere katılanların oranı ise \% 43,9, herhangi bir çevre etkinliğine katılanların oranı ise \%73,2 olarak gerçekleşmiştir. Katılımcıların \%57,2'si çevre ile ilgili yayınları izlediğini belirtmiştir.

Sivil toplum kuruluşlarında etkinlik gösteren yurttaşların çevresel tehdit algılamaları ve çevresel bilinç düzeyleri üçer boyutta ele alınırken çevre odaklı davranışları ise tek boyutta ele alınmıştır. Çevresel tehdit ölçeği boyutlarında en yüksek güvenilirlik atıklara dayalı tehdit boyutunda elde edilirken (Cronbach Alfa=0,80), en yüksek ortalama ise iklim değişikliğine dayalı tehdit boyutunda 4,63 ortalama ile (Grand Mean=4,63) elde edilmiştir. Çevresel bilinç ölçeği boyutlarında en yüksek güvenilirlik Yağmur Ormanları ve Sera Gazı bilgisi boyutunda elde edilirken (Cronbach Alfa=0,80), diğer iki çevresel bilgi boyutlarında 0,65 olarak hesaplanmıştır. Çevresel bilinç ölçeğinde en yüksek ortalama Nükleer ve Gen Bilgisi 4,1 ortalama ile elde edilmiştir. Çevre odaklı davranış ölçeğinin güvenilirliği Cronbach Alfa $=0,873$ hesaplanırken ortalaması ise 4,06 olacak şekilde hesaplanmıştır. Araştırmada kullanılan Çevresel tehdit ölçeği ve Çevresel bilinç ölçekleri bir bütün olarak ele alınmış ve güvenilirlikleri incelenmiş ve sırayla güvenilirlikleri 0,878 ve 0,826 olarak hesaplanmıştır. 
Sivil yurttaşların çevresel tehdit, çevresel bilinç ve çevre odaklı davranışlarında en yüksek ve en düşük duyarlılık gösterdikleri ifadeler ise her bir boyut için aşağıdaki gibi bulunmuştur. Buna göre;

Atıklara dayalı tehdit ölçeğinde en yüksek ortalama 4,62 ile 'Kıyı şeridinde (İzmir, İzmit, Gemlik v.b.) kontrolsüz endüstrileşme sonucu artan kirlilik' ifadesinde, en düşüğü ise 4,44 ile 'Katı atıklar' ifadesinde elde edilmiştir.

Nükleer kimyasal tehdit ölçeğinde en yüksek ortalama 4,53 ile 'Yeraltı madenlerin doğaya zarar veren yöntemlerle gün yüzüne çıkartılması' ifadesinde, en düşüğü ise 4,22 ile 'Nükleer enerji üretimi' ifadesinde elde edilmiştir.

İklim değişikliğine dayalı tehdit ölçeğinde en yüksek ortalama 4,68 ile 'İklim değişikliği-Küresel ısınma' ifadesinde, en düşüğü ise 4,52 ile 'Ozan tabakasının incelmesi' ifadesinde elde edilmiştir.

Nükleer ve Gen Bilgisi Çevresel Bilinç ölçeğinde en yüksek ortalama 4,24 ile 'GDO'lu (genetik yapısı ile oynanmış) ürünler insan sağlığını olumsuz etkileyen ürünler değildir' ifadesinde, en düşüğü ise 3,76 ile 'Elektro manyetik dalgalar canlıların genetik yapılarının değişmesinde etkili değildir' ifadesinde elde edilmiştir.

Yağmur Ormanları ve Sera Gazı Çevresel Bilinç ölçeğinde en yüksek ortalama 4,31 ile 'Yağmur ormanlarının azalması atmosferdeki oksijen miktarını azaltır' ifadesinde elde edilmiştir. En düşüğü ise 3,94 ile 'Karbondioksit, havada birikimi sonucu küresel ısınmaya neden olur 'ifadesi ile 3,95 ortalama ile 'Endemik sadece belli bölge veya yörelerde yaşayan canlılara verilen addır' ifadelerinde elde edilmiştir.

Yenilenebilir Enerji Elde Etme Bilgisi Çevresel Bilinç ölçeğinde en yüksek ortalama 4,31 ile 'Yenilenebilir enerji (rüzgârgülleri, güneş toplaçları gibi) geleceğin temiz enerji kaynağ olacaktır' ifadesinde, en düşüğü ise 3,75 ile 'Fosil yakıtlarının tüketimi atmosferdeki sera gazının artışına neden olarak küresel ısınmaya neden olur' ifadesinde elde edilmiştir.

Çevre Odaklı Davranış ölçeğinde en yüksek ortalama 4,56 ile 'Kâğıt, pil, plastik, pet, cam vb. gibi atıkları, yeniden değerlendirilebilmeleri için uygun geri dönüşüm kutularına atmayı uygun bulurum' ifadesinde elde edilmiştir. En düşüğü ise 4,00 ortalama ile 'Motor yağı, boya gibi zararlı kimyasal maddelerin kanalizasyona karışmamasına özen gösteririm' ifadesinde edilmiştir. Ayrıca 4,03 ortalama ile 'Çevreyi koruma adına yapılan gösteri-protesto-yürüyüş gibi tepkisel eylemlere katılabilirim' ifadesi ile 4,06 ortalama ile 'Çevreye saygılı olmayan firmaların ürünlerinden satın almam' ifadelerinde elde edilmiştir. Sonuçlar Tablo 1'de verilmiştir. 
Sosyal Bilimler Dergisi 39

Tablo 1. Çevresel Tehdit Çevresel Bilinç ve Çevresel Odaklı Davranış Ölçeklerine Ait Tanımlayıcı İstatistikler

\begin{tabular}{|c|c|c|c|}
\hline $\begin{array}{l}\text { Var } \\
\text { No }\end{array}$ & $\begin{array}{l}\text { Çevresel tehdit (Atıklara dayalı tehdit). Cronbach Alfa= 0,80. Genel } \\
\text { Ortalama (Grand Mean) }=4,53\end{array}$ & Ortalama & $\begin{array}{c}\text { Std. } \\
\text { Sapma }\end{array}$ \\
\hline 1 & Katı atıklar. & 4,44 & 0,840 \\
\hline 2 & $\begin{array}{l}\text { Kıyı şeridinde (İzmir, İzmit, Gemlik v.b.) kontrolsüz endüstrileşme sonucu } \\
\text { artan kirlilik. }\end{array}$ & 4,62 & 0,743 \\
\hline 3 & Endüstriyel bölgelerde (Yatağan, Kayseri, Uşak, v.b ) oluşan hava kirliliği. & 4,50 & 0,882 \\
\hline 4 & Nehirlerin (Gediz Nehri, Aksu, Çayı, Kura Nehri v.b) kirlenmesi. & 4,51 & 0,918 \\
\hline \multirow[t]{2}{*}{5} & Tarım ilaçları gibi kimyevi maddelerle yeraltı sularının kirlenmesi. & 4,59 & 0,769 \\
\hline & $\begin{array}{l}\text { Çevresel tehdit (Nükleer kimyasal tehdit). Cronbach Alfa= 0,74. Grand } \\
\text { Mean }=4,42\end{array}$ & & \\
\hline 6 & Nükleer enerji üretimi. & 4,22 & 1,171 \\
\hline 7 & Biyolojik çeşitlilik kaybı. & 4,43 & 1,004 \\
\hline 8 & Genetiği ile oynanmış (GDO) ürünler. & 4,47 & 0,956 \\
\hline 9 & Ülkelerin nükleer, kimyasal ve biyolojik silahlara sahip olması. & 4,45 & 0,881 \\
\hline \multirow[t]{2}{*}{10} & $\begin{array}{l}\begin{array}{l}\text { Yeraltı madenlerin doğaya zarar veren yöntemlerle gün yüzüne } \\
\text { çıartılması. }\end{array} \\
\end{array}$ & 4,53 & 0,805 \\
\hline & $\begin{array}{l}\text { Çevresel tehdit (İklim değişikliğine yönelik). Cronbach Alfa= 0,785. } \\
\text { Grand Mean= } 4,63\end{array}$ & & \\
\hline 11 & İklim değişikliği-küresel ısınma. & 4,68 & 0,710 \\
\hline 12 & Su kıtlığı -su kirliliği. & 4,66 & 0,678 \\
\hline 13 & Çölleşme -Ormansızlaşma -Toprak erozyonu. & 4,65 & 0,616 \\
\hline \multirow[t]{2}{*}{14} & Ozon tabakasının incelmesi. & 4,52 & 0,762 \\
\hline & $\begin{array}{l}\text { Çevresel bilinç (Nükleer ve Gen Bilgisi). Cronbach Alfa= 0,65. Grand } \\
\text { Mean=4,10 }\end{array}$ & & \\
\hline 15 & $\begin{array}{l}\text { Elektro manyetik dalgalar canlıların genetik yapılarının değişmesinde etkili } \\
\text { değildir.* }\end{array}$ & 3,76 & 1,141 \\
\hline 16 & $\begin{array}{l}\text { GDO'lu (genetik yapısı ile oynanmış) ürünler insan sağlığını olumsuz } \\
\text { etkileyen ürünler değildir.* }\end{array}$ & 4,24 & 1,143 \\
\hline 17 & $\begin{array}{l}\text { Yaşam alanları nükleer enerji santralleri yakınlarında olan canlılar olumsuz } \\
\text { etkilenecektir. }\end{array}$ & 4,21 & 1,079 \\
\hline \multirow[t]{2}{*}{18} & $\begin{array}{l}\text { Nükleer enerji elde etme yöntemi atıkları nedeni ile radyasyon ürettiğinden } \\
\text { doğaya zararlıdır. }\end{array}$ & 4,19 & 1,092 \\
\hline & $\begin{array}{l}\text { Çevresel bilinç (Yağmur Ormanları ve Sera Gazı). Cronbach Alfa= 0,80. } \\
\text { Grand Mean= 4,08 }\end{array}$ & & \\
\hline 19 & Yağmur ormanları en fazla canlı çeşitliliği olan yaşam alanlarıdır. & 4,14 & 1,007 \\
\hline 20 & Yağmur ormanlarının azalması atmosferdeki oksijen miktarını azaltır. & 4,31 & 0,900 \\
\hline 21 & $\begin{array}{l}\text { Sera gazlarının atmosferdeki oranının artması küresel ısınmaya neden } \\
\text { olmaktadır. }\end{array}$ & 4,08 & 0,964 \\
\hline 22 & $\begin{array}{l}\text { Canlı türlerin yok olmasında yaşam alanlarının bozulması en fazla etkiye } \\
\text { sahiptir. }\end{array}$ & 4,07 & 1,062 \\
\hline 23 & Karbondioksit, havada birikimi sonucu küresel ısınmaya neden olur. & 3,94 & 0,917 \\
\hline \multirow[t]{2}{*}{24} & Endemik sadece belli bölge veya yörelerde yaşan canlılara verilen addır. & 3,95 & 1,014 \\
\hline & $\begin{array}{l}\text { Çevresel bilinç (Yenilenebilir Enerji Elde Etme). Cronbach Alfa= 0,65. } \\
\text { Grand Mean= 4,08 }\end{array}$ & & \\
\hline
\end{tabular}




\begin{tabular}{|c|c|c|c|}
\hline 25 & $\begin{array}{l}\text { Fosil yakıtlarının tüketimi atmosferdeki sera gazının artışına neden olarak } \\
\text { küresel ısınmaya neden olur. }\end{array}$ & 3,75 & 1,059 \\
\hline 26 & $\begin{array}{l}\text { Enerji elde etmek için oluşturulan rüzgârgüllerinin yarardan çok zararı } \\
\text { vardır.* }\end{array}$ & 4,16 & 1,081 \\
\hline \multirow[t]{2}{*}{27} & $\begin{array}{l}\text { Yenilenebilir enerji (rüzgar gülleri, güneş toplaçları gibi) geleceğin temiz } \\
\text { enerji kaynağı olacaktır. }\end{array}$ & 4,31 & 0,960 \\
\hline & Çevre Odaklı Davranış. Cronbach Alfa=0,873. Grand Mean=4,06 & & \\
\hline 28 & $\begin{array}{l}\text { Çevreyi koruma adına yapılan gösteri-protesto-yürüyüş gibi tepkisel } \\
\text { eylemlere katılabilirim. }\end{array}$ & 4,03 & 0,913 \\
\hline 29 & Nükleer deneme yapan, hangi ülke olursa olsun protesto edilmelidir. & 4,27 & 0,947 \\
\hline 30 & $\begin{array}{l}\text { Çevremdeki insanları, ekolojik dengenin korunması konusunda duyarlı } \\
\text { olmaları için uyarırım. }\end{array}$ & 4,23 & 0,721 \\
\hline 31 & $\begin{array}{l}\text { Çevre konusunda yapılan seminer, panel, konferans gibi bilimsel } \\
\text { çalışmalara katılabilirim. }\end{array}$ & 4,19 & 0,739 \\
\hline 32 & $\begin{array}{l}\text { Çevre konusunda çalışan gönüllü kuruluşların kampanya ya da } \\
\text { çalışmalarına katılabilirim. }\end{array}$ & 4,13 & 0,775 \\
\hline 33 & $\begin{array}{l}\text { Kâğıt, pil, plastik, pet, cam vb. gibi atıkları, yeniden değerlendirilebilmeleri } \\
\text { için uygun geri dönüşüm kutularına atmayı uygun bulurum. }\end{array}$ & 4,56 & 0,732 \\
\hline 34 & $\begin{array}{l}\text { Ürünleri satın alırken doğa dostu ya da geri dönüşümlü ambalajlı olanlarını } \\
\text { tercih etmeye çalışırım. }\end{array}$ & 4,14 & 0,820 \\
\hline 35 & $\begin{array}{l}\text { Motor yağı, boya gibi zararlı kimyasal maddelerin kanalizasyona } \\
\text { karışmamasına özen gösteririm. }\end{array}$ & 4,00 & 0,902 \\
\hline 36 & Enerjiyi verimli kullanan ev aletlerini almaya çalışırım. & 4,30 & 0,735 \\
\hline 37 & Evdeki ampulleri daha az enerji tüketen ampul tiplerinden seçerim. & 4,46 & 0,721 \\
\hline 38 & Çevreye saygılı olmayan firmaların ürünlerinden satın almam. & 4,06 & 0,886 \\
\hline 39 & $\begin{array}{l}\text { İmkânım olsa kendi evimde yenilenebilir (güneş enerjisi, rüzgârgülü g.b) } \\
\text { enerji kullanırdım. }\end{array}$ & 4,48 & 0,699 \\
\hline
\end{tabular}

*Ters kodlu sorular olup veri analizinde olumlu hale getirilmişlerdir.

Sivil yurttaşların Çevreci tehdit algılaması ile Çevresel bilinç düzeylerini belirlemeye yönelik ölçeklerin ikinci düzey (Second Order) Doğrulayıcı Faktör Analizleri, çevre odaklı davranış ölçeğinin ise tek faktörlü doğrulayıcı faktör analizi yapılmıştır. Buna göre çevreci tehdit ölçeğinde $\chi^{2} / \mathrm{df}=3,45$ ve RMSEA $=0,075$ hesaplanmıştır. Çevresel bilinç ölçeğinde ise $\chi^{2} / \mathrm{df}=3,53$ ve RMSEA=0,076 olarak hesaplanmıştır. Çevre odaklı davranış ölçeğinde ise $\chi^{2} / \mathrm{df}=3,66$ ve $\mathrm{RMSEA}=0,078$ olarak elde edilmiştir.

Araştırmada kurulan yapısal eşitlik modelin sınanmasında elde edilen uyum ölçütleri; $\chi 2=1613,14 ; \quad$ d.f. $=692 ; \chi^{2} / \mathrm{df}=2,33$, RMSEA $=0,055$, NFI $=0,94, \mathrm{NNFI}=0,96, \mathrm{PNFI}=0,88, \mathrm{CFI}=0,96, \mathrm{IFI}=0,96, \mathrm{RFI}=0,93, \mathrm{RMR}=0,048$ olarak elde edilmiştir. Uyum ölçütlerine bakıldığında elde edilen yapısal modelin, kabul edilebilir olduğu söylenebilir. Sivil yurttaşların çevresel tehdit algısının, çevresel bilinç ve duyarlılığı nasıl etkilediğinin ve bu etkilerin çevre odaklı davranışı nasıl etkilediğine yönelik oluşturulan yapısal model Şekil 1'in sınanması Şekil 3 standart çözümü olarak elde edilmiştir. 


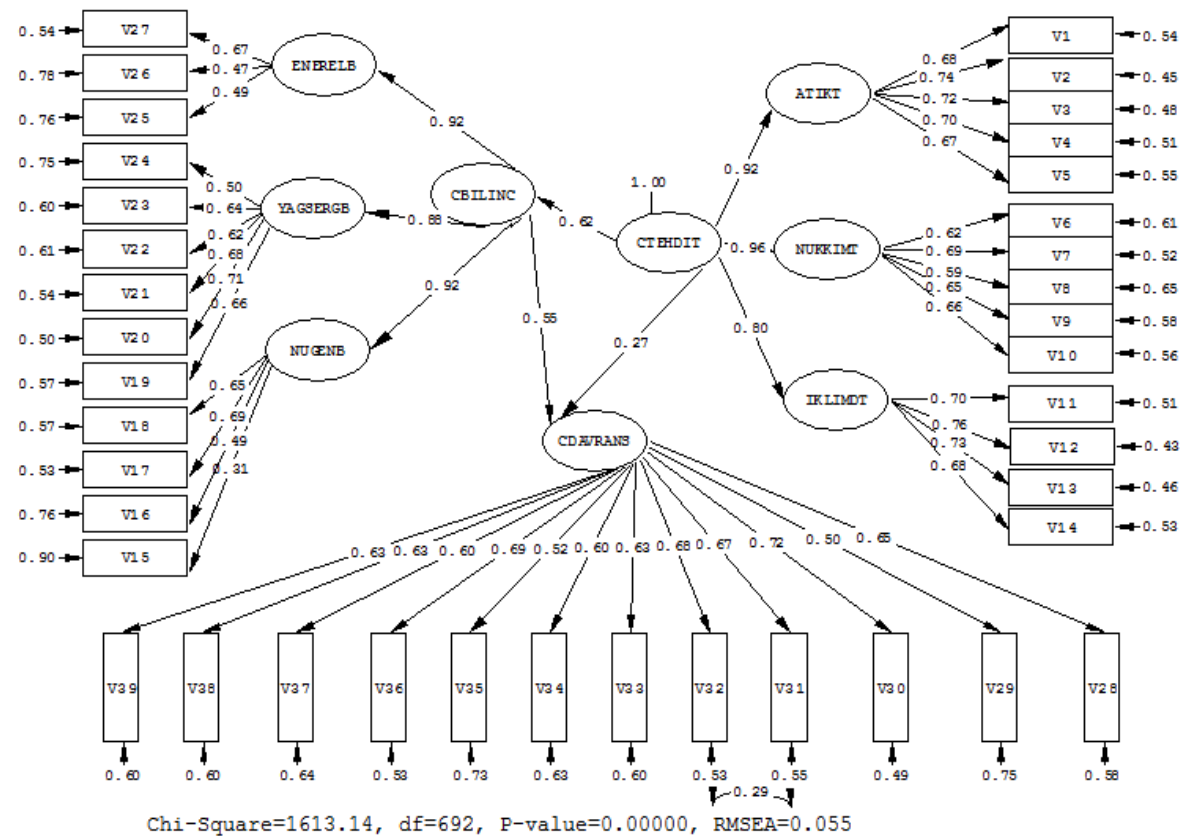

Şekil 3. Sivil Yurttaşların Çevresel Tehdit, Çevresel Bilinç

Çevre Odaklı Davranış Yapısal Modeli

Sivil Yurttaşların Çevre Odaklı Davranış Yapısal Modelinde yer alan tüm ilişki katsayıları (yollar) istatistiksel açıdan $\mathrm{p}<0,01$ anlam düzeyinde anlamlı bulunmuştur. Yapısal modelde elde edilen ilişkiler $t$ istatistiği ile sınanmakta ve en küçük $t$ değeri çevresel tehdit gizil değişkeni ile çevre odaklı davranış gizil değişkeninde $t=4.25$ olacak şekilde elde edilmiştir. Yapısal eşitlik modellemesi sonucunda elde edilen parametre tahminleri istatistiksel olarak anlamlı bulunmuş araştırmada kurulan tüm hipotezler desteklenmiştir. Elde edilen yapısal eşitliklerde

$$
\begin{array}{ll}
\text { CBILINC }=0,62^{*} \text { CTEHDIT, } & R^{2}=0,39 \\
\text { CDAVRANIS }=0,55^{*} \text { CBILINC }+0,27^{*} \text { CTEHDIT, } & R^{2}=0,56
\end{array}
$$

şeklinde yazılabilir.

Sivil yurttaşların çevresel tehdit algılamaları ve çevresel bilinç düzeyleri, çevre odaklı davranışlarını pozitif yönde etkilediği söylenebilir. Bu bağlamda sivil yurttaşların çevresel tehdit algılamasındaki bir birimlik artış, çevre odaklı davranışta 0,27 birim artışa neden olabileceği söylenebilir. Benzer şekilde yurttaşların çevresel bilinçlerindeki bir birimlik artışın çevre odaklı davranışta 0,55 birim artışa neden olabileceği söylenebilir. Ayrıca Çevresel tehdit algılamasındaki bir birimlik artışın, çevresel bilinçte 0,62 birimlik bir artışa neden olduğu söylenebilir. Yurttaşların çevresel tehdit 
algılaması çevresel bilinç değişiminin \% 39'ini açıklarken çevre odaklı davranışın \%7,3'ünü açıklamaktadır. Çevre odaklı davranıştaki değişimlerin \%56'sını çevreci tehdit algılaması ile çevresel bilinç birlikte açıklamaktadır.

Yapısal eşitlik modelleri araştırmacıya gizil değişkenlerin açıklanmasında gözlenen değişkenlerin katkılarını ya da ilişkilendikleri değişim miktarlarını da vermektedir. İlişkileri yüksek olan değişkenin ilişkilendiği değişim de daha yüksek olmaktadır. Bu katkılar iki türlü açıklanabilmektedir. Her bir yola ait ilişkilerin karesi $\left(R^{2}\right)$ alınarak ya da 1 'den hata teriminin çıkartılması ile hesaplanabilmektedir.

Çevresel tehdit ölçeği ikinci düzey özelliğe sahip olup üç gizil değişkenle açıklanmaktadır. Bu üç gizil değişken içinde en yüksek ilişki 0,96 birimlik bir ilişki ile nükleer ve kimyasal tehdit gizil değişkeninde elde edilmiştir. Sivil yurttaşların nükleer ve kimyasal tehdit algılamasında gerçekleşen bir birimlik artış çevresel tehdit algılamasında 0,96 birimlik bir artışa neden olmaktadır. Ayrıca bireylerin nükleer ve kimyasal tehdit algılaması, çevresel tehdit gizil değişkenindeki değişimlerin 0,92 birimi ile ilişkilenmektedir.

Sivil yurttaşların çevresel tehdit ile atıklara dayalı tehdit algılamaları arasında 0,92 birimlik bir ilişki bulunmuş olup, sivil yurttaşların atıklara dayalı tehdit algılamasında gerçekleşen bir birimlik artma, çevresel tehdit algılamalarında 0,92 birimlik bir artışa neden olmaktadır. Atıklara dayalı tehdit algılamalarının, çevresel tehdit algılamasında 0,85 birimlik bir değişimle ilişkilenmekte olduğu bulunmuştur.

Sivil yurttaşların iklim değişikliği tehdit algılaması ile çevresel tehdit algılaması arasında aynı yönde 0,80 birimlik bir ilişki bulunmuş olup, iklim değişikliği tehdit algılamasında gerçekleşen bir birimlik artma çevresel tehdit algılamasında 0,80 birimlik artışa neden olduğu bulunmuştur. Sivil yurttaşların iklim değişikliği tehdit algılaması çevresel tehdit gizil değişkeninde 0,64 birimlik bir değişkenle ilişkilendiği belirlenmiştir.

Çevresel bilinç ölçeği ikinci düzey özelliğe sahip olup üç gizil değişken tarafından açıklanmaktadır. Çevresel bilinç gizil değişkeni ile en yüksek ilişkiye sahip gizil değişkenler 0,92 birimlik ilişki ile enerji elde etme bilinci ile nükleer ve genetik bilincinde elde edilmiştir. Sivil yurttaşların bu gizil değişkenlerde gerçekleşen bir birimlik artış çevresel bilinçlerinde 0,92 birimlik bir katkı yaratmakta olduğu belirlenmiştir. Ayrıca bu gizil değişkenler çevresel bilinç gizil değişkeninde 0,85 birimlik bir değişkenlikle ilişkilendikleri belirlenmiştir.

Sivil yurttaşların yağmur ormanları ve sera gazlarına yönelik bilinçleri ile çevresel bilinçleri arasında aynı yönde 0,88 birimlik bir ilişki bulunmuştur. Sivil yurttaşların yağmur ormanları ve sera gazlarına yönelik 
bilinçlerinde gerçekleşen bir birimlik artış çevresel bilinç düzeylerinde 0,88 birimlik bir artışa neden olmaktadır. Ayrıca çevresel bilinç düzeylerindeki değişimlerin 0,77' siyle ilişkilendiği belirlenmiştir.

Sivil yurttaşların çevresel davranış algılamaları tek düzeyli belirlenmiş olup ikinci düzey gizil değişkenlere sahip değildir. Çevre merkezli davranış değişkenlerinden V31 ile V32 arasında modifikasyona gidilmiştir.

Çevresel davranış gizil değişkenine en yüksek katkı veren gözlenen değişken 0,72 birimlik bir ilişki ile V30 değişkeni vermektedir. V30 'Çevremdeki insanları, ekolojik dengenin korunması konusunda duyarlı olmaları için uyarırım' değişkenin ilişkilendiği değişim ise $0,72^{2}=0,51$ birim olarak hesaplanmaktadır. $\mathrm{Bu}$ değer $1-0,49=0,51$ şeklinde de hesaplanabilmektedir. Diğer değişkenler içinde benzer şekilde hesaplanabileceği aşikârdır.

Nükleer enerji üretimi, biyolojik çeşitlilik kaybı gibi değişkenlerden oluşan nükleer ve kimyasal tehdit (NUKKIMT) gizil değişkenine en yüksek katkıyı 'Biyolojik Çeşitlilik Kaybı' 0,69 ile en düşük katkıyı ise 0,59'luk ilişki ile 'Genetiği ile oynanmış (GDO) ürünler' değişkeninde elde edilmiştir.

İklim değişikliğine (IKLIMDT) dayalı olan tehdit gizil değişkenine en yüksek katkı sağlayan gözlenen değişken 0,76'lik bir ilişki ile 'Su Kıtlığ1Su Kirliliğii' ve en az katkı sağlayan ise 0,68'lık bir ilişki ile 'Ozon Tabakasının İncelmesi' değişkeni olmuştur.

Sanayileşmenin sonucunda atıklara dayalı çevre kirlenmesine yönelik oluşan çevresel tehdit (ATIKT) birinci düzey gizil değişkeninde 0,74 ile en yüksek katkıyı sağlayan 'Kıyı şeridinde (İzmir, İzmit, Gemlik v.b.) Kontrolsüz Endüstrileşme Sonucu Artan Kirlilik' gözlenen değişkeninde elde edilmiştir. En düşük katkı ise 0,67 ile 'Tarım ilaçları gibi kimyevi maddelerle yeraltı sularının kirlenmesi' gözlenen değişkeninde elde edilmiştir.

STK üyelerinin yağmur ormanları ve sera gazlarına yönelik bilgi boyutunda (YAGSERGB) en çok katkıya sahip gözlenen değişken 0,71 ile 'Yağmur ormanlarının azalması atmosferdeki oksijen miktarını azaltır' değişkeninde elde edilmiştir. En az katkıya sahip değişken ise 0,50 ile 'Endemik sadece belli bölge veya yörelerde yaşan canlılara verilen addır' gözlenen değişkeninde elde edilmiştir.

Nükleer gen bilgisi NUGENB gizil değişkeninde, gözlenen değişkenlerin katkılarına bakıldığında, 0,69 ile 'Yaşam alanları nükleer enerji santralleri yakınlarında olan canlılar olumsuz etkilenecektir' değişkeni nükleer ve gen bilgisi boyutunda en yüksek katkıya sahip bulunmuştur. En 
az katkı ise 0,31 ile 'Elektro manyetik dalgalar canlıların genetik yapılarının değişmesinde etkili değildir' değişkenlerinde elde edilmiştir.

Enerji elde etme ENERELB bilgisine yönelik boyutta en yüksek katkıyı 0,67 ile 'Yenilenebilir enerji (rüzgârgülleri, güneş toplaçları gibi) geleceğin temiz enerji kaynağ 1 olacaktır' değişkeninde elde edilirken en az katkı ise 0,47 ile 'Enerji elde etmek için oluşturulan rüzgârgüllerinin yarardan çok zararı vardır' değişkenlerinde elde edilmiştir.

Araştırmanın ikinci aşamasına yönelik bulgular ise aşağıdaki gibi elde edilmiştir. Araştırmaya katılanların \%63,8'i erkek yurttaşlardan oluşmaktadır. Katılımcıların ortalama yaşı 38,02 standart sapması ise 13,174 olarak hesaplanmıştır. Medeni durumları ise $\% 61,5^{\prime}$ inin evli, $\% 35,8^{\prime}$ inin ise herhangi bir çevre derneğine üye olduğu belirlenmiştir. Katılımcıların eğitimleri incelendiğinde $\% 42,9^{\prime} \mathrm{u}$ Lisans, $\% 11,9^{\prime} \mathrm{u}$ Lisansüstü eğitime sahip olduğu belirlenmiştir. Ön lisans eğitime sahip yurttaşların oranı ise \%19,0 olarak hesaplanmıştır. Ortalama aylık gelirleri ise 1635,75 ve standart sapması ise 1229,309 şeklinde hesaplanmıştır. Çevre ile ilgili son iki yıl içinde eğitim ya da seminere katılanların oranı ise $\% 44,7$, herhangi bir çevre etkinliğine katılanların oranı ise $\% 74,5$ olarak gerçekleşmiştir. Katılımcıların $\% 56,9 '$ ' çevre ile ilgili yayınları (gazete-dergi yazıları ve TV programları gibi) izlediğini belirtmiştir. Yayınları izlemeyenlerin oranı ise \%1,6 olarak gerçekleşmiştir. Geriye kalan \%41,5'i ise bazen yayınları izlediğini belirtmiştir.

Sivil toplum kuruluşlarında etkinlik gösteren yurttaşların, çevresel bilinç düzeyleri üç boyutta ele alınırken, çevresel tutum boyutu iki, çevre odaklı davranışları ise tek boyutta ele alınmıştır. Çevresel bilinç ölçeği boyutlarında en yüksek güvenilirlik (Cronbach Alfa=,727) ve en düşük ortalama 3,954 ile atıklar küresel ısınma boyutunda elde edilmiştir. Çevresel tutum ölçeğinde ise en yüksek güvenilirlik (Cronbach Alfa=,87) ve 4,323 ortalama duygusal tutum ölçeğinde elde edilmiştir. Çevre odaklı davranış ölçeğinin alt boyutları olmayıp ölçeğin güvenilirliği için Cronbach Alfa istatistiği 0,886 olarak hesaplanmış ve bu ölçeğin genel ortalaması ise 4,249 olarak hesaplanmıştır. Çevresel bilinç ve Çevresel tutum ölçekleri bir bütün olarak ele alınmış ve güvenilirlik analizleri yapılmıştır. Buna göre Çevresel bilinç ölçeğinin güvenilirliği için Cronbach Alfa istatistiği 0,868 genel ortalaması ise 4,06 bulunmuştur. Çevresel tutum ölçeğinin ise Cronbach Alfa istatistiği 0,866, genel ortalaması ise 4,202 olarak hesaplanmıştır.

Yağmur ormanları gen bilgisi ölçeğinde en yüksek ortalama 4,29 ile 'Yağmur ormanlarının azalması atmosferdeki oksijen miktarını azaltır' ifadesinde en düşüğü ise 3,96 ile 'Endemik sadece belli bölge veya yörelerde yasan canlılara verilen addır' ifadesinde elde edilmiştir. 
Atıklar küresel 1sınma bilgisi ölçeğinde en yüksek ortalama 4,27 ile 'Ozon tabakasının delinmesi cilt kanserine neden olabilmektedir' ifadesinde, en düşüğü ise 3,67 ile 'Zirai ilaç kullanımı toprak kirliliğine neden olmaz' ifadesinde elde edilmiştir.

Enerji elde etme bilgisi ölçeğinde en yüksek ortalama 4,30 ile 'Yenilenebilir enerji (rüzgar gülleri, güneş toplaçları gibi) geleceğin temiz enerji kaynağı olacaktır' ifadesinde, en düşüğü ise 3,79 ile 'Elektro manyetik dalgalar canlıların genetik yapılarının değişmesinde etkili değildir' ifadesinde elde edilmiştir.

Duygusal tutum ölçeğinde en yüksek ortalama 4,48 ile 'Sanayi kuruluşlularının ya da kentlerin atıklarının arıtma işlemlerinden geçirilmeden deniz veya akarsulara verilmesi beni endişelendiriyor' ifadesinde, en düşüğ ü ise 4,06 ile 'Sivil toplum kuruluşlarının çevre duyarlılığı konusunda yetersiz kalması beni sinirlendiriyor' ifadesinde elde edilmiştir.

Bilişsel tutum ölçeğinde en yüksek ortalama 4,60 ile 'Hayvanlar ve bitkiler de en az insanlar kadar yasam hakkına sahiptirler' ifadesinde, en düşüğü ise 3,32 ile 'Ülkelerin kendi doğal kaynaklarını istedikleri gibi kullanmalarına Birleşmiş Milletler dahil hiçbir kurum ya da kuruluş karışmamalıdır' ifadesinde elde edilmiştir.

Çevre Odaklı Davranış ölçeğinde en yüksek ortalama 4,58 ile 'Kâğıtt, pil, plastik, pet, cam vb. gibi atıkları, yeniden değerlendirilebilmeleri için uygun geri donuşum kutularına atmayı uygun bulurum' ifadesinde, en düşüğü ise 3,58 ile 'Temizlik maddelerini, zararlı kimyasal maddeler içerip içermediğine dikkat ederek satın alırım' ifadesinde elde edilmiştir. Sonuçlar Tablo 2'de verilmiştir.

Tablo 2. Çevresel Bilinç, Çevresel Tutum ve Çevresel Davranış Ölçeğine Ait Tanımlayıcı İstatistikler

\begin{tabular}{|c|l|c|c|}
\hline $\begin{array}{c}\text { Var } \\
\text { No }\end{array}$ & $\begin{array}{l}\text { Çevresel Bilinç (Yağmur ormanları gen bilgisi) Cronbach Alfa= 0,653. Grand } \\
\text { Mean = 4,141 }\end{array}$ & $\begin{array}{c}\text { Ortala } \\
\text { ma }\end{array}$ & $\begin{array}{c}\text { Std. } \\
\text { Sapma }\end{array}$ \\
\hline 1 & Yağmur ormanları en fazla canlı çeşitliliği olan yasam alanlarıdır. & 4,13 & 1,002 \\
\hline 2 & Yağmur ormanlarının azalması atmosferdeki oksijen miktarını azaltır. & 4,29 & 0,912 \\
\hline 3 & Canlı türlerin yok olmasında yasam alanlarının bozulması en fazla etkiye sahiptir. & 4,09 & 1,040 \\
\hline 4 & Endemik sadece belli bölge veya yörelerde yasan canlılara verilen addır. & 3,96 & 1,012 \\
\hline 5 & $\begin{array}{l}\text { GDO'lu (genetik yapısı ile oynanmış) ürünler insan sağlı̆̆ını olumsuz etkileyen } \\
\text { ürünler değildir* }\end{array}$ & 4,23 & 1,139 \\
\hline & $\begin{array}{l}\text { Çevresel Bilinç (Atıklar küresel ısınma). Cronbach Alfa=0 ,727. } \\
\text { Grand Mean = 3,954 }\end{array}$ & 4,07 & 0,963 \\
\hline 6 & Sera gazlarının atmosferdeki oranının artması küresel ısınmaya neden olur. & 3,67 & 1,386 \\
\hline 7 & Zirai ilaç kullanımı toprak kirliliğine neden olmaz* & & \\
\hline
\end{tabular}




\begin{tabular}{|c|c|c|c|}
\hline 8 & $\begin{array}{l}\text { Fosil yakıtlarının tüketimi atmosferdeki sera gazi artısına neden olarak küresel } \\
\text { ısınmaya neden olur. }\end{array}$ & 3,76 & 1,055 \\
\hline 9 & Kâğıt toprağa zarar vermeden çözünebilen bir maddedir. & 3,75 & 1,085 \\
\hline 10 & Ozon tabakasının delinmesi cilt kanserine neden olabilmektedir. & 4,27 & 0,897 \\
\hline 11 & Araba aküsü doğa için tehlikeli bir atik olarak değerlendirilir. & 4,04 & 0,939 \\
\hline 12 & Karbondioksit, havada birikimi sonucu küresel ısınmaya neden olur. & 3,93 & 0,916 \\
\hline \multirow[t]{2}{*}{13} & İklim değişikliği eko sistemi olumsuz değiştirecektir. & 4,14 & 1,009 \\
\hline & $\begin{array}{l}\text { Çevresel Bilinç (Enerji elde etme bilgisi). Cronbach Alfa=0,669. Grand Mean= } \\
4,136\end{array}$ & & \\
\hline 14 & $\begin{array}{l}\text { Güneş toplaçları (Güneş Enerjisi) doğal hayata herhangi bir zararlı etkisi } \\
\text { bulunmayan enerji elde etme yöntemidir. }\end{array}$ & 4,17 & 0,927 \\
\hline 15 & $\begin{array}{l}\text { Elektro manyetik dalgalar canlıların genetik yapılarının değişmesinde etkili } \\
\text { değildir*. }\end{array}$ & 3,79 & 1,129 \\
\hline 16 & Enerji elde etmek için oluşturulan rüzgârgüllerinin yarardan çok zararı vardır*. & 4,18 & 1,069 \\
\hline 17 & $\begin{array}{l}\text { Yenilenebilir enerji (rüzgar gülleri, güneş toplaçları gibi) geleceğin temiz enerji } \\
\text { kaynağı olacaktır. }\end{array}$ & 4,30 & ,979 \\
\hline 18 & $\begin{array}{l}\text { Yasam alanları nükleer enerji santralleri yakınlarında olan canlılar olumsuz } \\
\text { etkilenecektir. }\end{array}$ & 4,19 & 1,102 \\
\hline \multirow[t]{2}{*}{19} & $\begin{array}{l}\text { Nükleer enerji elde etme yöntemi atıkları nedeni ile radyasyon ürettiğinden doğaya } \\
\text { zararlıdır. }\end{array}$ & 4,20 & 1,086 \\
\hline & Çevresel tutum (Duygusal tutum). Cronbach Alfa= 0,87. Grand Mean= 4,323 & & \\
\hline 20 & $\begin{array}{l}\text { Resmi kurumların çevre kirliliğini kontrol etmek için önlem almaması beni çileden } \\
\text { çıkarıyor. }\end{array}$ & 4,29 & 0,890 \\
\hline 21 & $\begin{array}{l}\text { Sivil toplum kuruluşlarının çevre duyarlılığı konusunda yetersiz kalması beni } \\
\text { sinirlendiriyor. }\end{array}$ & 4,06 & 0,873 \\
\hline 22 & $\begin{array}{l}\text { Çvre kirliliğinin bitki ve hayvan yaşamına verdiği zararları düşündükçe } \\
\text { sinirleniyorum. }\end{array}$ & 4,31 & 0,753 \\
\hline 23 & $\begin{array}{l}\text { Gazete, TV gibi iletişim araçlarında çevre kirliliğiyle ilgili yayınlara yeterince yer } \\
\text { verilmediği için kızıyorum. }\end{array}$ & 4,20 & 0,826 \\
\hline 24 & $\begin{array}{l}\text { Çevre kirliliğinin devam etmesi dünyayı yaşanılmaz bir ortama sürükleyeceğinden } \\
\text { korkuyorum. }\end{array}$ & 4,42 & 0,722 \\
\hline 25 & $\begin{array}{l}\text { Sanayi kuruluşlularının ya da kentlerin atıklarının arıtma işlemlerinden } \\
\text { geçirilmeden deniz veya akarsulara verilmesi beni endişelendiriyor. }\end{array}$ & 4,48 & 0,747 \\
\hline 26 & Ülkelerin nükleer, kimyasal ve biyolojik silahlara sahip olması beni huzursuz ediyor. & 4,35 & 0,817 \\
\hline
\end{tabular}


Sosyal Bilimler Dergisi 47

\begin{tabular}{|c|c|c|c|}
\hline 27 & Baz istasyonlarının giderek artması beni kaygılandırıyor. & 4,34 & 0,777 \\
\hline 28 & Türkiye'de güneş enerjisi kullanımının yaygınlaşması beni mutlu eder. & 4,44 & 0,755 \\
\hline \multirow[t]{2}{*}{29} & Çevresel tutum (Bilişsel tutum). Cronbach Alfa=0,751. Grand Mean=4,118 & & \\
\hline & $\begin{array}{l}\text { Ülkelerin kendi doğal kaynaklarını istedikleri gibi kullanmalarına Birleşmiş } \\
\text { Milletler dahil hiçbir kurum ya da kuruluş karışmamalıdır*. }\end{array}$ & 3,32 & 1,472 \\
\hline 30 & $\begin{array}{l}\text { Türkiye'de desteklenmesi gereken daha önemli projeler olduğu halde Dünya } \\
\text { Bankası'nın hava kirliliğini ölçme projelerini desteklemesi gereksizdir*. }\end{array}$ & 4,02 & 1,159 \\
\hline 31 & $\begin{array}{l}\text { Konut ve is yerlerinde doğalgaz kullanmanın hava kirliliği sorununun çözümüne } \\
\text { bir katkısı olmayacağını düşünüyorum*. }\end{array}$ & 3,92 & 1,071 \\
\hline 32 & Deniz, akarsu ve gollerin kirlendiği haberlerinin abartıldığını düşünüyorum*. & 4,18 & 1,071 \\
\hline 33 & $\begin{array}{l}\text { İnsanların doğaya egemen olma çabalarının, çevresel felaketler getireceğini } \\
\text { düşünüyorum. }\end{array}$ & 4,31 & 0,833 \\
\hline 34 & $\begin{array}{l}\text { Madenlerimizin siyanürle gün yüzüne çlkartılmasında siyanürün eko sisteme zarar } \\
\text { verdiğini düşünmüyorum*. }\end{array}$ & 4,06 & 1,330 \\
\hline 35 & İnsanlar yaşamlarını sürdürebilmek için doğayla uyum içinde yaşamalıdırlar. & 4,46 & 0,861 \\
\hline 36 & $\begin{array}{l}\text { Çevre sorunları aslında insanlık için buğun tanımlandığı düzeyde büyük bir sorun } \\
\text { değildir*. }\end{array}$ & 4,05 & 1,256 \\
\hline 37 & $\begin{array}{l}\text { Günümüzde yeni türeyen (domuz gribi, kus gribi, kirim Kongo kanamalı ateşi gibi) } \\
\text { hastalıkların birçoğu doğal dengenin bozulmasından kaynaklanmaktadır. }\end{array}$ & 3,80 & 1,168 \\
\hline 38 & $\begin{array}{l}\text { Yoksulluk, açlık, kuraklık, insanların yerleşme yerlerinin kalitesi, nükleer enerji, } \\
\text { savaşlar, ülkeler arası gelişmişlik farklılıkları gibi diğer konuların da çevre } \\
\text { sorunlarının bir boyutu olarak düşünüyorum. }\end{array}$ & 4,03 & 0,949 \\
\hline 39 & $\begin{array}{l}\text { Eğer doğa ile ilgili önlemler alınmadan kirlenme devam ederse yakında büyük bir } \\
\text { çevre felaketi ile karsılaşabiliriz. }\end{array}$ & 4,40 & 0,750 \\
\hline 40 & Hayvanlar ve bitkiler de en az insanlar kadar yasam hakkına sahiptirler. & 4,60 & 0,692 \\
\hline \multirow[t]{2}{*}{41} & $\begin{array}{l}\text { Çevre ile ilgili kampanyalara katılmayı bir vatandaşlık borcu olarak } \\
\text { düşünmekteyim. }\end{array}$ & 4,37 & 0,754 \\
\hline & Çevre Odaklı Davranış. Cronbach Alfa=0,886. Grand Mean= 4,249 & & \\
\hline 42 & $\begin{array}{l}\text { Kâğıt, pil, plastik, pet, cam vb. gibi atıkları, yeniden değerlendirilebilmeleri için } \\
\text { uygun geri donuşum kutularına atmayı uygun bulurum. }\end{array}$ & 4,58 & 0,731 \\
\hline 43 & $\begin{array}{l}\text { Ürünleri satın alırken doğa dostu ya da geri dönüşümlü ambalajlı olanlarını tercih } \\
\text { etmeye çalışırım. }\end{array}$ & 4,14 & 0,821 \\
\hline 44 & $\begin{array}{l}\text { Çevreyi koruma adına yapılan gösteri-protesto-yürüyüş gibi tepkisel eylemlere } \\
\text { katılabilirim. }\end{array}$ & 4,04 & 0,912 \\
\hline 45 & $\begin{array}{l}\text { Temizlik maddelerini, zararlı kimyasal maddeler içerip içermediğine dikkat ederek } \\
\text { satın alırım. }\end{array}$ & 3,83 & 0,947 \\
\hline 46 & $\begin{array}{l}\text { Motor yağı, boya gibi zararlı kimyasal maddelerin kanalizasyona karışmamasına } \\
\text { özen gösteririm. }\end{array}$ & 4,02 & 0,886 \\
\hline 47 & $\begin{array}{l}\text { Çevremdeki insanları, ekolojik dengenin korunması konusunda duyarlı olmaları } \\
\text { için uyarırım. }\end{array}$ & 4,23 & 0,726 \\
\hline 48 & $\begin{array}{l}\text { Çevre konusunda yapılan seminer, panel, konferans gibi bilimsel çalışmalara } \\
\text { katılabilirim. }\end{array}$ & 4,20 & 0,735 \\
\hline 49 & $\begin{array}{l}\text { Çevre konusunda çalışan gönüllü kuruluşların kampanya ya da çalışmalarına } \\
\text { katılabilirim. }\end{array}$ & 4,13 & 0,778 \\
\hline 50 & Enerjiyi verimli kullanan ev aletlerini almaya çalışırım. & 4,31 & 0,747 \\
\hline 51 & $\begin{array}{l}\text { İmkânım olsa kendi evimde yenilenebilir (güneş enerjisi, rüzgârgülü g.b) enerji } \\
\text { kullanırdım. }\end{array}$ & 4,48 & 0,696 \\
\hline 52 & $\begin{array}{l}\text { Tercih yapmak durumunda olduğumda çevreye daha az zarar veren yada zarar } \\
\text { vermeyen ürüne yönelirim }\end{array}$ & 4,37 & 0,704 \\
\hline 53 & Kullandığım su ve elektrik miktarlarını azaltmak için caba gösteririm & 4,39 & 0,755 \\
\hline 54 & Sentetik girdili gıda ürünlerinin neden olduğu hastalıklara (kanser, alerjiler, vb) & 4,51 & 0,638 \\
\hline
\end{tabular}


karsı koruyucu önlem alınmasını desteklerim.

Sivil yurttaşların Çevresel bilinç ile Çevresel tutum ölçeği düzeylerini belirlemeye yönelik ölçeklerin ikinci düzey (Second Order) Doğrulayıcı Faktör Analizleri, çevre odaklı davranış ölçeğinin ise tek faktörlü doğrulayıcı faktör analizi yapılmıştır. Buna göre çevresel bilinç ölçeğinde $\chi^{2} / \mathrm{df}=3,32, \quad$ RMSEA $=0,073, \quad \mathrm{NNFI}=0,94$ ve $\mathrm{CFI}=0,95$ olarak hesaplanmıştır. Çevresel Tutum ölçeğinde ikinci düzey doğrulayıcı faktör analizinde ise $\chi^{2} / \mathrm{df}=3,36$, $\mathrm{RMSEA}=0,080$, NNFI $=0,94$ ve $\mathrm{CFI}=0,95$ olarak hesaplanmıştır. Çevresel Davranış doğrulayıcı faktör analizinde ise $\chi^{2} / \mathrm{df}=4,11$, RMSEA $=0,074$, NNFI $=0,93$ ve $\mathrm{CFI}=0,95$ olarak hesaplanmıştır. Elde edilen bu istatistiklerin ölçekler için doğrulayıcı faktör analizi sonuçlarının kabul edilebilir olduğunu göstermektedir.

Araştırmanın ikinci aşamasında kurulan yapısal eşitlik modelin sınanmasında elde edilen uyum ölçütleri $\chi^{2} / \mathrm{df}=2,96$, RMSEA=0,067, $\mathrm{NFI}=0,93, \mathrm{NNFI}=0,96$ ve $\mathrm{CFI}=0,96$ olarak elde edilmiştir. Elde edilen uyum iyilikleri çerçevesinde modelin en az kabul edilebilir uyum ölçüsüne sahip olduğu söylenebilir.

Sivil yurttaşların çevresel bilinç algısının, çevresel tutum ve davranışı nasıl etkilediğine yönelik oluşturulan yapısal model Şekil 4'deki gibi elde edilmiştir. Şekil 4 standart çözümü göstermektedir. Sivil Yurttaşların Çevre Odaklı Davranış Yapısal Modelinde yer alan tüm ilişki katsayıları (yollar) istatistiksel açıdan $\mathrm{p}<0,01$ anlam düzeyinde anlamlı bulunmuştur. Yapısal modelde elde edilen ilişkiler $t$ istatistiği ile sınanmakta ve en küçük $t$ değeri çevresel bilinç gizil değişkeni ile çevresel davranış gizil değişkeninde $t=2,37$ olacak şekilde elde edilmiştir.

Yapısal eşitlik modellemesi sonucunda elde edilen parametre tahminleri istatistiksel açıdan anlamlı bulunmuş ve araştırmada kurulan tüm hipotezler doğrulanmıştır. Elde edilen Yapısal Eşitlikler ;

$$
\begin{array}{ll}
\text { CTUTUM }=0,80^{*} \text { CBILINC, } & \mathrm{R}^{2}=0,63 \\
\text { CDAVRAN }=0,64^{*} \text { CTUTUM }+0,18^{*} \text { CBILINC, } & \mathrm{R}^{2}=0,72
\end{array}
$$

şeklinde yazılabilir.

Sivil yurttaşların çevresel bilinçlerinin ve çevreci tutumlarının artmasının, çevresel davranışların üzerinde artırıcı etki gösterdiği söylenebilir. Yurttaşların çevresel bilinçlerindeki bir birimlik artış çevresel tutumlarında 0,80 birim artışa neden olmaktadır. Çevresel tutumlarındaki bir birimlik artış ise çevresel davranışlarında 0,64 birimlik bir artışa neden olmaktadır. Çevresel bilinçlerindeki bir birimlik artış ise çevresel davranışlarında 0,18 birimlik bir artışa neden olduğu söylenebilir. Ayrıca 
Çevresel tutumdaki değişimin \%63'ünü Sivil yurttaşların çevresel bilinçleri açıklayabilmektedir. Benzer şekilde yapısal eşitlik modelinden hareketle Çevresel davranıştaki değişimlerin \%72'isini çevresel tutum ve bilinç açıklayabilmektedir.

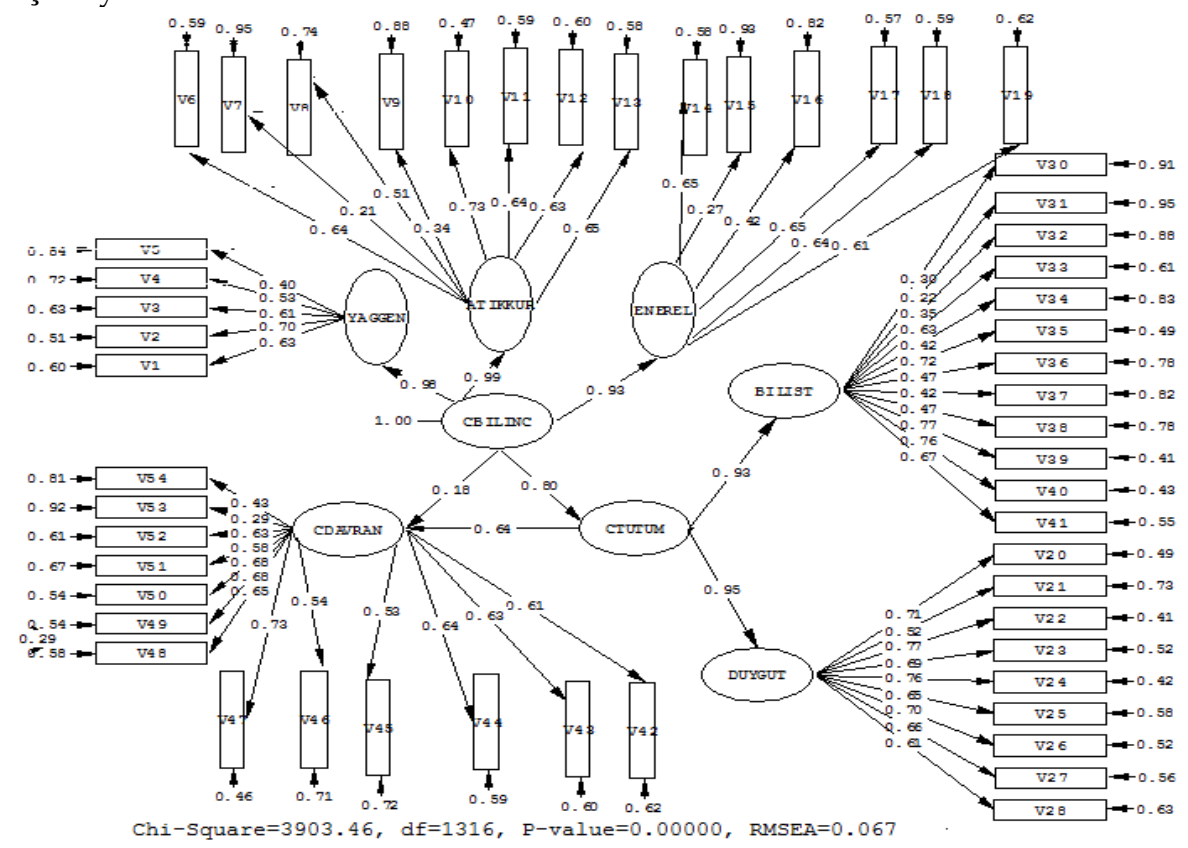

Şekil 4. Sivil Yurttaşların Çevresel Bilinç, Çevresel Tutum Çevre Odaklı Davranış Yapısal Modeli

Gizil değişkenler arasında ya da gizil değişkenler ile gözlenen değişkenler arasındaki ilişkiler incelendiğinde; çevreci tutum (CTUTUM) gizil değişkeninin ikinci düzey özelliğe sahip olduğu ve duygusal tutum gizil değişkeni ile aynı yönde 0,95 birimlik ilişkiye sahip olduğu bulunmuştur. Yurttaşların duygusal tutumlarında gerçekleşen bir birimlik artış çevreci tutumlarında 0,95 birimlik bir artışa neden olurken 0,90 birimlik bir değişkenlikle ilişkilendiği bulunmuştur.

Yurttaşların bilişsel tutumları ile çevreci tutumları arasında aynı yönde 0,93 birimlik bir ilişki bulunurken, bilişsel tutumda gerçekleşen bir birimlik artış çevreci tutumlarda 0,93 birimlik bir artışa neden olduğu bulunmuştur. Ayrıca bilişsel tutum, çevresel tutumda 0,86 birimlik bir değişkenlikle ilişkilenmektedir.

Yurttaşların çevresel bilinçlerine yönelik gizil değişkenler arasında aynı yönde ilişki bulunmuştur. Yurttaşların enerji elde etme bilinçlerinde 
(ENEREL) gerçekleşen bir birimlik artış çevresel bilinçlerinde 0,93 birimlik bir artışa neden olurken 0,86 birimlik bir değişkenle ilişkilenmiştir. Yurttaşların atıklar ve küresel ısınma bilinçlerinde (ATIKKUR) gerçekleşen bir birimlik artış çevresel bilinçlerinde 0,99 birimlik bir artışa neden olurken yağmur ormanları ve gen bilgilerinde (YAGGEN) gerçekleşen bir birimlik artış 0,98 birimlik bir artışa neden olduğu belirlenmiştir.

Sivil yurttaşların çevreci davranışları tek düzeyde belirlendiğinden direk gözlenen değişkenlerle açılanmıştır. $\mathrm{Bu}$ bağlamda yurttaşların Çevreci davranışlarında en yüksek katkıya sahip gözlenen değişken 0,73 ile V47 'Çevremdeki insanları, ekolojik dengenin korunması konusunda duyarlı olmaları için uyarırım' ifadesinde elde edilmiştir. En az etki ise 0,29 ile 'Kullandığım su ve elektrik miktarlarını azaltmak için çaba gösteririm' V53 gözlenen değişkeninde elde edilmiştir.

Duygusal tutum (DUYGUT) gizil değişkeninde en yüksek katkı1 sağlayan ya da en yüksek ilişkili olan gözlenen değişken 0,77 ile 'Çevre kirliliğinin bitki ve hayvan yaşamına verdiği zararları düşündükçe sinirleniyorum' ifadesi yer almıştır. En az katkı ise 0,52'lik bir ilişki katsayısı ile 'Sivil toplum kuruluşlarının çevre duyarlılığı konusunda yetersiz kalması beni sinirlendiriyor' ifadesinde elde edilmiştir.

Bilişsel Tutum (BILIST) gizil değişkeninde en yüksek ilişkili olan değişken 0,77 ile V39 'Eğer doğa ile ilgili önlemler alınmadan kirlenme devam ederse yakında büyük bir çevre felaketi ile karsılaşabiliriz' ifadesinde elde edilmiştir. En az ilişkili değişken ise 0,22'lik bir ilişki ile V31 'Konut ve iş yerlerinde doğalgaz kullanmanın hava kirliliği sorununun çözümüne bir katkısı olmayacağını düşünüyorum' ifadesinde elde edilmiştir

Atıklar ve küresel ısınma gizil değişkeninde (ATIKKUR) en yüksek etkiye sahip ifade 0,73'lik bir ilişki ile V10 'Ozon tabakasının delinmesi cilt kanserine neden olabilmektedir' en az etki ise 0,21 ilişki ile V7 'Zirai ilaç kullanımı toprak kirliliğine neden olmaz' ifadesinde elde edilmiştir.

Sivil yurttaşların Enerji elde etme (ENEREL) bilinçlerinde en yüksek ilişki 0,65'lik ilişkiyle V17 'Yenilenebilir enerji (rüzgârgülleri, güneş toplaçları gibi) geleceğin temiz enerji kaynağı olacaktır' ifadesinde elde edilirken, en az etki ise 0,27'lik bir ilişki ile V15 'Elektro manyetik dalgalar canlıların genetik yapılarının değişmesinde etkili değildir' ifadesinde elde edilmiştir.

Sivil yurttaşların yağmur ormanları ve gen bilgisi (YAGGEN) boyutuna en yüksek katkıyı sağlayan ifade 0,70'lik ilişki ile V2 'Yağmur ormanlarının azalması atmosferdeki oksijen miktarını azaltır' bilinçlerinde elde edilmiştir. En az etki ise 0,40'lık bir ilişki ile V5 'GDO'lu (genetik yapısı 
Sosyal Bilimler Dergisi 51

ile oynanmış) ürünler insan sağlığını olumsuz etkileyen ürünler değildir' ifadesinde elde edilmiştir.

Çanakkale ilinde sivil toplum kuruluşlarında etkinlik gösteren sivil yurttaşların çevreci davranışlarında Çevresel tutumlarının katkısı Çevresel bilinçlerinden daha yüksek bulunmuş ve yurttaşların çevresel bilinçleri artarken çevresel tutumları da artmakta olduğu bulunmuştur. Benzer şekilde çevresel bilinç artarken çevreci davranışları da artmaktadır. Yurttaşların çevresel tutumları artarken çevresel davranışları da artmakta olduğu belirlenmiştir. Araştırmada ele alınan tüm gizil değişkenler arasındaki ilişkiler pozitif yönlü olup gizil değişkenlerdeki artışlar, yurttaşların çevresel bilinçlerini, tutumlarını ve davranışlarını artırmaktadır. Dolayısıyla araştırmanın ilk aşamasında olduğu gibi ikinci aşamasında da ele alınan tüm hipotezler doğrulanmıştır.

\section{Sonuç}

Araştırmanın her iki aşamasında sivil toplum kuruluşlarında etkinlik gösteren sivil yurttaşların çevresel tehdit algılamaları ve çevresel bilinçlerinin çevre merkezli davranışlarını etkileyip etkilemediğinin belirlenmesi çalışmasında yapısal eşitlik modelinden yararlanılmıştır. Yapısal Eşitlik Modeli'ne göre STK üyelerinin, günümüzde karşılaştığımız çevre tehditlerin, çevreci davranışlarını daha duyarlı hale getirdiği ve çevreci davranışlarını artırdığı belirlenmiştir. Benzer şekilde, STK üyelerinin çevresel tehdit algılamalarının çevreci bilinç düzeylerini de artırdığı belirlenmiştir. Çevre bilinci yüksek olan STK üyelerinin daha fazla çevreci davrandıkları görülmüştür. Dolayısıyla sivil yurttaşların Çevreci bilinçleri, çevreci tehdit algılamaları ile çevre merkezli davranışları arasında aracılık yaptığı ifade edilebilir. Yurttaşların çevre merkezli davranışlarında çevreci bilinçleri en yüksek, çevreci tehdit algılamaları ise daha az katkıya sahip olduğu belirlenmiştir.

Çevresel tehdit algılaması üç faktörde toplanmıştır. Bu faktörlerden çevresel tehdit algılamasına en yüksek katkıyı nükleer ve kimyasal sorunlara yönelik oluşan boyut sağlamıştır. Dolayısıyla en yüksek tehdit algılaması nükleer ve kimyasal tehdit olarak belirlenmiştir. En az tehdit algılaması ise iklim değişikliğine yönelik gizil değişkeninde elde edilmiştir. Bu anlamda Çanakkale STK'nda yer alan yurttaşlar günümüzün belki de en önemli sorunu olan küresel iklim değişikliği tehdit algılamasını, endüstrileşme sonucu atıklara dayalı tehdit algılamasından daha az önemli bulmuşlardır.

STK üyelerinin yağmur ormanları ve sera gazlarına yönelik bilinç boyutunda en çok katkıya sahip gözlenen değişken 'Yağmur ormanlarının azalması atmosferdeki oksijen miktarını azaltır' değişkeninde elde 
edilmiştir. En az katkıya sahip değişken ise 'Endemik sadece belli bölge veya yörelerde yaşan canlılara verilen addır' gözlenen değişkeninde elde edilmiştir. Bu boyutta en teknik özelliğe sahip soru 'Sera gazlarının atmosferdeki oranının artması küresel ısınmaya neden olmaktadır' ifadesinde yer almaktadır. Oysa 'Endemik sadece belli bölge veya yörelerde yaşan canlılara verilen addır' ifadesi daha kolay yanitlanabilecek bir soru olup ölçekte daha fazla ağırlığa sahip olması beklenirdi. Çünkü Türkiye'nin kendine has bir bitki ve canlı çeşitliliğine sahip İda Dağı Çanakkale sınırları içinde bulunmaktadır. Bu araştırmanın yapıldığı dönemde STK'lar, özellikle çevre örgütleri İda Dağı'ndaki siyanürle altın aramalarına karşı bilgilendirme toplantıları yapmakta ve İda Dağı'ndaki altın aramalarına yönelik maden şirketlerini protesto ediyorlardı. Bu anlamda en yüksek katkının endemik canlı çeşitliliğine yönelik ifadenin yer aldığı sorudan elde edilmesi beklenirdi.

'Yaşam alanları nükleer enerji santralleri yakınlarında olan canlılar olumsuz etkilenecektir' değişkeni nükleer ve gen bilgisi boyutunda en yüksek katkıya sahip bulunmuştur. En az katkı ise 'Elektro manyetik dalgalar canlıların genetik yapılarının değişmesinde etkili değildir' değişkenlerinde elde edilmiştir. Bu boyutta sivil yurttaşların GDO'lu ürünlerle ilgili bilgilerinin ortalaması en yüksek iken, YEM'e göre nükleer ve gen bilgisi gizil değişkenine en yüksek katkıyı vermemiştir. Oysaki araştırma, GDO'lu ürünlerin iletişim araçlarında tartışılan ve sağlığa verdiği zararların çok önemli olduğunun bilgisinin verildiği bir dönemde gerçekleştirilmişti. Dolayısıyla GDO'lu ürünlerin katkısının daha yüksek olması beklenebilirdi. STK lı yurttaşlar GDO'lu ürünlere yönelik oluşturulan ifadeyi YEM'e göre çok da önemli bulmamışlardır.

STK'lı yurttaşlar yenilenebilir enerji kaynakları konusundaki yaklaşımları her ne kadar olumlu gözlense de fosil yakıtların çevreyi kirlettiği ve küresel isınmaya neden olduğu bilinmektedir. İlişki katsayılarına bakıldığında 1'e yakın olmaması yurttaşların geleneksel enerji elde etme ya da kullanma alışkanlıklarından kaynaklanabileceğini gösterebilir.

Araştırmanın ikinci aşamasında da Yapısal Eşitlik Modeli'nden yararlanılmış ve yapısal modele göre STK üyelerinin, çevresel tutumlarının çevreci davranışlarını daha duyarlı hale getirdiği ve çevreci davranışlarını artırdığı belirlenmiştir. Benzer şekilde, STK üyelerinin çevresel bilinç algılamalarının çevresel tutumlarını artırdığ 1 belirlenmiştir. Çevre bilinci yüksek olan STK üyelerinin daha fazla çevresel davranış gösterdikleri belirlenmiştir. Dolayısıyla sivil yurttaşların Çevresel tutumları, çevresel bilinç algılamaları ile çevre merkezli davranışları arasında aracılık yaptığı 
Sosyal Bilimler Dergisi 53

ifade edilebilir. Yurttaşların çevre merkezli davranışlarında çevresel tutumları en yüksek, çevresel bilinçleri ise daha az katkıya sahip olduğu belirlenmiştir.

Araştırmanın ilk aşamasında sivil yurttaşların çevresel tutumları dikkate alınmamıştır. Ayrıca Çevresel tutum ölçeğine yanıt vermeyen katılımcılar ölçekten çıkarılmış ve ankete katılan yeni katılımcılarla analize devam edilmiştir. Dolayısıyla araştırmanın ilk aşamasında kullanılan Çevresel bilinç ölçeğinin boyutları değişmeler olmuş ve değişken sayısı da 13 den 19'a çıkartılmıştır. 19 değişkene ait Çevresel bilinç ölçeği araştırmanın birinci aşamasında olduğu gibi üç boyutta incelenmiştir.

STK üyelerinin yağmur ormanları ve gen bilgisine yönelik bilinç boyutunda en çok katkıya sahip gözlenen değişken 'Yağmur ormanlarının azalması atmosferdeki oksijen miktarını azaltır' değişkeninde elde edilmiştir. Bu değişken araştırmanın ilk aşamasında da en çok katkıya sahip bulunmuştur. En az katkıya sahip değişken ise 'GDO'lu (genetik yapısı ile oynanmış) ürünler insan sağlığını olumsuz etkileyen ürünler değildir' değişkeninde elde edilmiştir. Araştırmanın ilk aşamasında bahsedildiği gibi ikinci aşamasında da bu değişkenin en az öneme sahip olması sivil yurttaşların, GDO'lu ürünlerin zararlı ürünler olmayabileceği şeklinde algıladıkları söylenebilir. Araştırmada bu boyutta yer alan 'Endemik sadece belli bölge veya yörelerde yasan canlılara verilen addır' ifadesi en küçük ortalamaya sahip olup araştırmanın ilk aşamasında elde edilen sonucu doğrular niteliktedir.

Atıklara ve küresel ısınmaya yönelik olan bilinç boyutuna en yüksek katkıyı sağlayan değişken 'Ozon tabakasının delinmesi cilt kanserine neden olabilmektedir' değişkeninde elde edilmiş. Türkiye'de çevre kirliliğinin ilk söylemleri arasında bu değişkenin yer alması sivil yurttaşlar tarafından bir olgu olarak algılandığı şeklinde yorumlanabilir.

Çanakkale'de bulunan STK'larda yer alan sivil yurttaşların enerji elde etme bilgisine dayalı olan çevresel bilinçleri araştırmanın her iki aşamasında aynı sonuçları vermiştir. Sivil yurttaşlar geleceğin enerji kaynaklarının yenilenebilir enerji kaynağı olması yönünde görüş bildirmişlerdir.

Araştırmanın ikinci aşamasında yer alan çevresel tutum ölçeği bilişsel ve duygusal tutum olmak üzere ele alınmıştır. Sivil yurttaşlar yaşadığımız sistemde kirlenmeyi önleyici tedbirler alınmaz ise felaketlerin ola bileyeceği kanısını taşımaktadırlar. Ayrıca bu kirlenmenin bitki hayvan yaşamına da olumsuz etkilediği kanısını da duygusal tutumlarında belirtmişlerdir. 
STK'lar günümüzde hayatın pek çok alanında itici güç olarak rol almaktadırlar. Bu bakımdan çevresel bilinç düzeyinin tüm topluma yayılması, STK'ların genel bilinç düzeyinin arttırılması ve bu yönde toplum genelinde farkındalık yaratacak çalışmalar yapılması ve toplumu bilinçlendirici etkinlikler düzenlemesiyle mümkündür. Dolayısıyla tarımda, sanayide, turizmde, genel hizmetler sektöründe vb. yaşamın her alanında çevre duyarlılığı ve çevresel bilincin arttırılması, hem sektörel sürdürülebilirliğin sağlanması hem de yaşam kalitesinin korunması, arttırılması ve sürdürülebilir kılınması açısından önemlidir. Bu bakımdan, turizm gibi çevreye bağımlı olan tüm sektörlerde verimliliğin arttırılması ve sürdürülebilirliğin sağlanması, ilgili sektörlerden dolaylı ya da doğrudan etkilenen tüm paydaşların çevresel bilinç düzeyinin arttırılması açısından önemlidir. Son yıllarda ortaya çıkan, sürdürülebilir turizm, eko-turizm, tarım turizmi, kırsal turizm, çiftlik turizmi vb., çevresel tahribatı en düşük düzeye çekebilecek ve aynı zamanda bilinç düzeyini en yüksek düzeye çıkarabilecek sektörel atılımlar özendirilmelidir.

Sonuç olarak; sivil toplum kuruluşlarında etkinlik gösteren sivil yurttaşların çevresel tehdit algılamalarının, çevresel bilinçlerinin ve çevresel tutumlarının çevre merkezli davranışlarını etkileyip etkilemediğinin belirlenmesi çalışmasında yapısal eşitlik modelinden yararlanılmıştır. Araştırmanın ilk aşamasında, sivil yurttaşların çevresel tehdit algılamaları ve çevresel bilinçlerinin çevre merkezli davranışlarına olası etkileri araştırılmıştır. Yurttaşların Çevresel tehdit algılamalarının çevresel bilinci artırıcı özelliğe sahip olduğu bulunmuş ve aynı zamanda çevresel tehdit algılamasının çevresel davranışı olumlu yönde artırıcı özellik taşıdığı belirlenmiştir. Benzer şekilde sivil yurttaşların çevresel bilinci ile çevre merkezli davranışları arasında aynı yönlü bir ilişki bulunmuş ve çevresel bilincin çevresel davranışı artırdığı belirlenmiştir. Ayrıca sivil yurttaşların çevresel tehdit algılamasın çok çevresel bilinçlerinin davranışı daha fazla etkilediği bulunmuştur.

Araştırmanın ikinci aşamasında STK üyelerinin, çevresel tutumlarının çevreci davranışlarını daha duyarlı hale getirdiği ve çevreci davranışlarını artırdığı belirlenmiştir. Benzer şekilde, çevresel bilinç algılamalarının çevreci tutumlarını artırdığı belirlenmiştir. Çevre bilinci yüksek olan STK üyelerinin daha fazla çevresel davranış gösterdikleri belirlenmiştir. Dolayısıyla sivil yurttaşların Çevresel tutumları, çevresel bilinç algılamaları ile çevre merkezli davranışları arasında aracılık yaptığ ifade edilebilir. Yurttaşların çevre merkezli davranışlarında çevresel tutumları en yüksek, çevresel bilinçleri ise daha az katkıya sahip olduğu belirlenmiştir. 
Sosyal Bilimler Dergisi 55

\section{Kaynaklar}

Aguilar S.(2002). "Environmental Non Government Organizations in Argentina", Reciel 11 (2) 2002. Issn 09628797.

Al-Rabaani A., bin H, Al-Mekhlafi S. S. M. (2009). "Attitudes of Sultan Qaboos University Students towards Some Environmental Problems and their Willingness to Take Action to Reduce them" Journal of Social Sciences 5 (1): 9-15.

Betsill, M. B., Corell, E. (2001).“NGO Infuence in International Environmental Negotiations: A Framework for Analysis", Global Environmental Politics 1:4, November.

Beyhan, Ş. G., Ünügür, S. M. (2005). Çağdaş Gereksinimler Bağlamında Sürdürülebilir Turizm ve Kimlik Modeli. İ.T.Ü. Mimarlı, Planlama, Tasarm, Cilt. 4, Sayı. 2, 79-87.

Demir, C., Çevirgen, A. (2006). Turizm ve Çevre Yönetimi: Sürdürülebilir Gelişme Yaklaşımı. Nobel Yayın Dağıtım, Ankara.

Duran, E. (2011). Turizm, Kültür ve Kimlik İlişkisi; Turizmde Toplumsal ve Kültürel Kimliğin Sürdürülebilirliği, İ.T.İC.Ü. Sosyal Bilimler Dergisi, Y11. 10, Say1. 19. ss, 289-313.

Hebel L. F., Montpied P., Fontanieu, V. (2010). “Students' Attitudes Toward The Environment: The Results of The French Secondary School Students Survey". XIV IOSTE Symposium, June 13-18, Bled, Slovenia. http://files.ecetera.si/IOSTE/presentation.html. Download. 19.01.2012.

Keating, M. (1996). Yeryüzü Zirvesinde Değişimin Gündemi-Gündem 21 ve Diğer Rio Anlaşmalarının Popüler Metinleri. Çev: UNEP Türkiye Yayın Komitesi, UNEP Türkiye Komitesi Yayını, Önder Matbaası: Ankara.

Nomuro, K., Hendarti, L., Abe, O. (2003). NGO Environmental Education Centers in Developing Countries: Role, Significance and Keys to Success, from a "Change Agent" Perspective. International Review for Environmental Strategies. 4 (2), 165- 82. $\quad$ EBSCO veri tabanından (Academic Search Premier) http://www.ebsco.com.

Vlaardingerbroek B., Taylor T.G.N. (2007). “The Environmental Knowledge and Attitudes of Prospective Teachers in Lebanon: A Comparative 
B. HAMARAT, O. GÜLER, E. DURAN, M. GÜMÜŞ, E. TUFAN | 56

Study", International Research in Geographical and Environmental Education, Vol. 16, No. 2.

WTO. (1998). Guide for Local Authorities on Developing Sustainable Tourism. World Tourism Organization: Madrid.

Yavetz, B., Goldman D., Pe'er, S. (2007). "Environmental Literacy in Teacher Training: Attitudes, Knowledge, and Environmental Behavior of Beginning Students", The Journal Of Environmental Education, Fall 2007, Vol. 39, No. 1.

Yılmaz V., Yıldız Z., Arslan T. (2011). Üniversite Öğrencilerinin Çevresel Duyarlılıkları İle Çevresel Davranışlarının Yapısal Eşitlik Modeliyle Araştırılması. Dumlupınar Üni. Sosyal Bilimler Dergisi. Sayı: 30, ss:271278.

Yılmaz, V. (2004). Consumer behaviour of shopping center choice. Social Behavior and Personality, Vol. 32, Issue: 8, 783-790).

Zecha, S. (2010). "Environmental knowledge, attitudes and actions of Bavarian (southern Germany) and Asturian (northern Spain) adolescents", International Research in Geographical and Environmental Education, Vol. 19, No. 3. 